\title{
Indicators of agricultural soil genesis under varying conditions of land use, Steppe Crimea
}

\author{
Fedor Lisetskii $^{\text {a }}$, Vladimir F. Stolba ${ }^{\text {b,* }}$, Olga Marinina ${ }^{\text {a }}$ \\ a Belgorod State National Research University, 308015, Belgorod, ul. Pobedy 85, Russia \\ ${ }^{\mathrm{b}}$ Aarhus University, Nordre Ringgade 1, DK-8000 Aarhus C, Denmark
}

\section{A R T I C L E I N F O}

\section{Article history:}

Received 12 May 2014

Received in revised form 29 October 2014

Accepted 8 November 2014

Available online 20 November 2014

\section{Keywords:}

Soil formation

Idle lands

Agrogenic soils

Chronosequence

Agrogenic indicators

Crimea

\begin{abstract}
A B S T R A C T
This study investigates the effects of agricultural exploitation of soils of the north-western Crimea, the active and large-scale cultivation of which began with the Greek colonization of the area. In order to compare soils using a wide spectrum of physical and chemical properties, the studied objects (virgin land, post-antique idle land, continually plowed land, modern-day plowed land, idle land of the modern era) have been grouped into a chronosequence. This makes it possible to apply the method of factor sequences of agrogenic transformations in soils, which takes into account different periods of human activities. The other factors involved in soil formation are considered to be relatively invariable. From the mass of physiochemical properties of these soils that have endured long-term agricultural stress, the most informative indicators of agrogenesis have been identified. The authors propose a procedure for calculating an integral agrophysical soil indicator based on five parameters that can be used to determine the soil structure and cloddiness as well as water-stability, the amount of waterstable aggregates and their mean mass-weighted diameter. Based on the estimates of their agrophysical state, the following sequence has been determined for the soils studied: Post-antique idle land $<$ virgin land $<$ idle land of the modern era $<$ continuously plowed land $<$ modern-day plowed land. It has been established that the previous practices of land use favorably affect the agrophysical properties of soils.

The loss of organic carbon in continually plowed land is 51\%, while in modern-day plowed and idle lands it amounts to $39 \%$ and $27-32 \%$ respectively. The reproduction of soil organic matter (SOM) and its quality, particularly of its labile content, which is responsible for the agrophysical properties of a plow horizon, is central to soil fertility management for sustainable agriculture. One observed effect of long-term agrogenic stresses in plowed horizons of Chernozems is a decrease in microelements such as $\mathrm{Co}, \mathrm{Ni}, \mathrm{Mn}, \mathrm{Cu}, \mathrm{Zn}, \mathrm{Pb}$, as well as phosphorus and potassium. It is estimated that the micronutrient content of plowed land is $5-6 \%$ lower than that of virgin soils. Even after 2280 years of renaturation, soils of post-antique idle lands preserve in their pedomemory the signs of agrogenesis. In terms of soil quality, the overall agrogenic transformation of soils cultivated during the recent period (the last $150-165$ years) is $15 \%$ lower than that of the continually plowed lands. The fallowing regime provides conditions that allow soils to regenerate within a few decades. The use of renaturation effects that mimic the fallowing regime opens up new possibilities for resource-saving sustainable agriculture.

This study, therefore, shows the informative potential of soils that have continuously, or with restorative periods, been subjected to long-term agrogenic impacts under different practices of land use. It also considers how this information may be actively employed to comprehend the long-term transformations of the material and energetic organization of soils.
\end{abstract}

(c) 2014 Elsevier B.V. All rights reserved.

\section{Introduction}

Land resources constitute the major production means in agriculture and will remain fundamental for provision of plant and animal food for the foreseeable future. Pedogenic processes are heterochronous; many of them, such as those related to soil fertility reproduction, take hundreds, if not thousands of years. In order to develop resource-saving

\footnotetext{
* Corresponding author.

E-mail address: klavs@cas.au.dk (V.F. Stolba).
}

technologies of land use, which could prevent soil degradation, it is important to understand trends in the long-term changes observed for the material and energetic organization of soils under different practices of land use. Along with the experimentally worked fields where functional transformations in the system "agrotechnologies-soils" are observed over many decades (Blake et al., 2000), soils in regions with a long agrarian history, which have experienced continuous, or with restorative periods, anthropogenic impacts, can be very informative. Soil agrogenic features that result from pedogenesis on an evolutionary scale only become apparent after a considerable period of agrogenesis. 
Eventually, anthropogenic processes lead to the formation of anthropogenic soils, which stimulate an on-going development of soil classification (Bryant and Galbraith, 2003).

Multidisciplinary investigations of the soil agrogenesis influenced by ancient arable agriculture have a very wide geography: Western Europe and particularly the Mediterranean (Ruecker et al., 1998; Sanchez-Maranon et al., 2002; Scalenghe et al., 2002; Delgado et al., 2007; Freppaz et al., 2008; Bellin et al., 2009; Stanchia et al., 2012); Eastern Europe, including its central part (Dolotov, 1984; Karavaeva, 2000; Polyakova and Platonycheva, 2012), the regions of Greco-Roman land use in Southern Ukraine (Lisetskii, 2008; Lisetskii and Rodionova, 2012) and the Crimea (Cordova and Lehman, 2005; Lisetskii et al., 2013) as well as the northern Caucasus (Korobov and Borisov, 2013); Asia (Lisitsyna and Kostyuchenko, 1976; Kostyuchenko and Lisitsyna, 1976; Gong et al., 2000; Wilkinson, 2003; Miyaji, 2003; Pietsch and Mabit, 2012); Africa (Mighall et al., 2012; Nyberg et al., 2012) and the New World (Sandor et al., 1990; Dick et al., 1994; Eash and Sandor, 1995; Sandor and Eash, 1995; Harden, 1996; Sandor, 2006; Goodman-Elgar, 2008; Londono, 2008; Homburg and Sandor, 2011; Fonte et al., 2012).

The present study aims to identify the most informative indicators of agrogenesis from a wider group of physicochemical properties of soils, which continuously, or with restorative phases, underwent longterm agricultural stress. This task benefits from the diversity of soils in the areas of the northern Black Sea littoral that have been affected by the Greek colonization.

\section{Study area}

The Tarkhankut Peninsula (NW Crimea) is part of the Crimean steppe plain (Fig. 1), the tectonically conditioned relief of which is dominated by the elevation of the same name with the maximum height of $179 \mathrm{~m}$. This elevation is formed primarily by karst limestones and is overlaid with loess-like, occasionally fairly thin, loams. Deep ravines and dells dissect the slopes of the anticlines (uvals). Typical of the upper levels are petrophytic steppes and wavy, rising and descending plains with gravelly Calcic Chernozems and Lithic Leptosols on the eluvia of parent limestone (IUSS Working Group WRB, 2014). Meanwhile, at the lower levels there are the slightly undulating plains and slopes of the dells and ravines with Petrocalcic Chernozems and some remnants of petrophytic steppes.

This area is characterized by a considerable natural diversity and an extremely complicated evolutionary history. The area is also notable for its varied terrain, diverse character and thickness of the pre-Pliocene, Pliocene and anthropogenic strata, as well as specific histories of the Late Cainozoic pedogenesis, climate and continental salt accumulation. The anthropogenic soils show traces of significant xeromorphy (Veklich and Sirenko, 1974). In the Late Holocene, the Sub-Atlantic was characterized by less dramatic changes in landscape than the Sub-Boreal, and by a climate that was cooler than during the Atlantic period (Matviishina, 2010).

The climate of the Tarkhankut Peninsula, which protrudes into the non-freezing Black Sea, is very arid (340-350 mm of precipitation per year) with moderately hot summers and mild winters, the average temperatures of July and January being $23{ }^{\circ} \mathrm{C}$ and $-3{ }^{\circ} \mathrm{C}$ respectively; the duration of the frost-free period is 200 days. The humidity coefficient (ratio of the annual precipitation to the annual evaporation) is 0.39-0.42. The insolation rate, $2300-2400 \mathrm{~h} / \mathrm{year}$, is highest in the Crimea.

The climate of the Crimean western coast (area of Eupatoria) differs from that of the Tarkhankut Peninsula by being slightly warmer (the average annual temperature is $0.5{ }^{\circ} \mathrm{C}$ higher) and moister (coefficient of humidity is 0.46 ), and the expenditure of radiation energy for pedogenesis is $110 \mathrm{MJ} / \mathrm{m}^{2}$ per year higher (Lisetskii and Ergina, 2010).

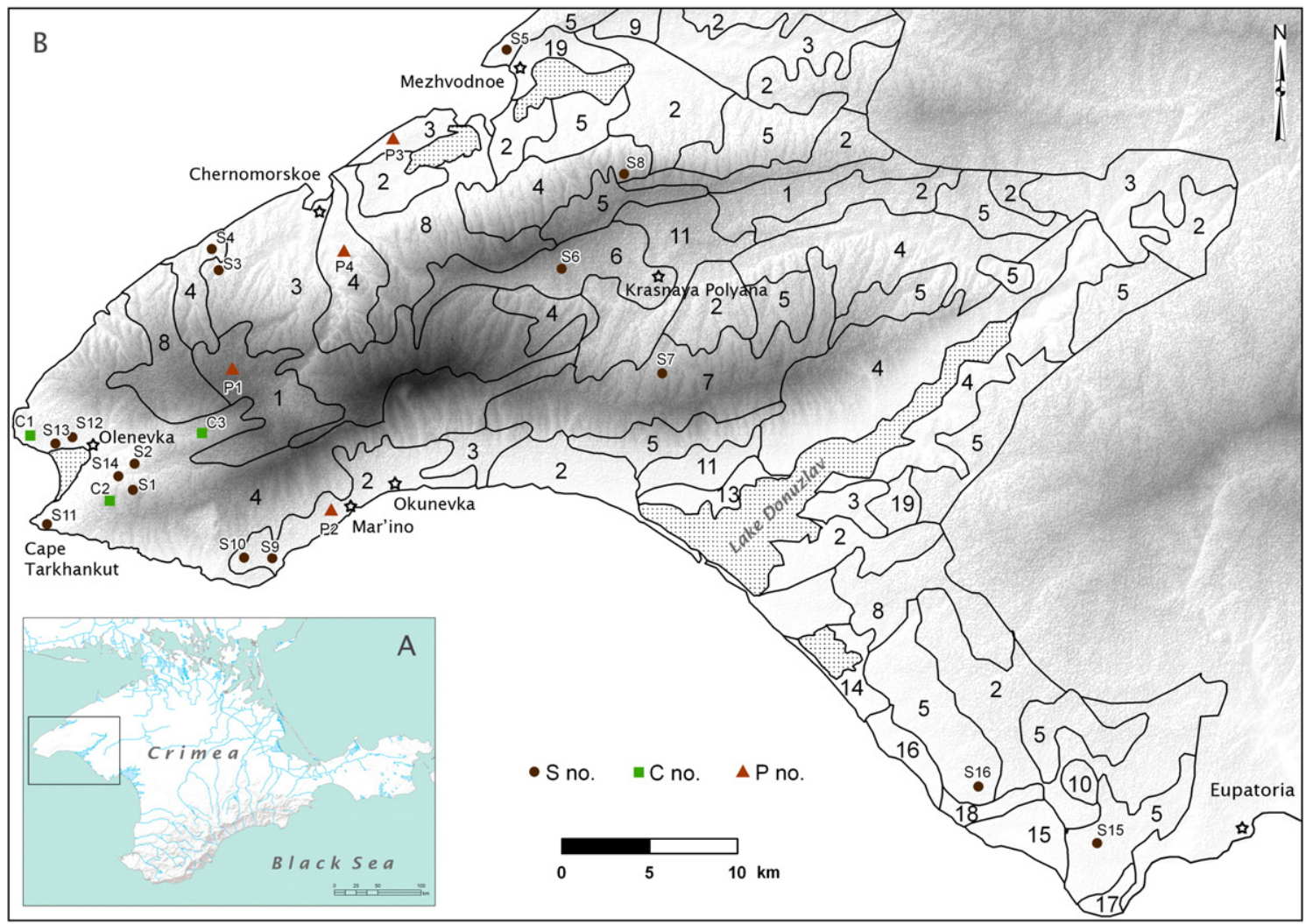

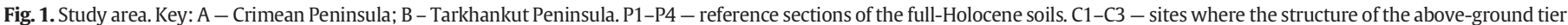

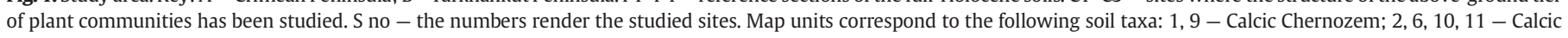
Chernozem (Secondary carbonates); 3, 5 - Petrocalcic Chernozem; 4, 7, 8 - Rendzic Leptosol (Skeletic); 12-19-azonal soils including those of different salinity. 
The data available, such as the emergence of settlements, finds of bronze sickles (Kolotukhin, 2003; Stolba, 2012) and fossil grain remains (Korpusova and Lyashko, 1990), as well as pollen of cerealia in the bottom sediments of mineral lakes (Sapelko and Subetto, 2007; Stolba et al., 2012), suggests that agriculture has existed in the area since the Bronze Age (second half of the 3rd and the 2nd millennia $\mathrm{BC}$ ), when local pastoralist societies will have made the transition to a more sedentary mode of life. However, it was not until around $360 \mathrm{BC}$ when the Greek colonists from Chersonesos occupied the region that a wide web of rural settlements emerged, and the area was divided for large-scale and regular exploitation of the land and soil resources. By around $270 \mathrm{BC}$, however, the Chersonesean countryside (chora) had become desolate following nomadic attacks, which perhaps were triggered by abrupt climatic changes (Stolba, 2005a, 2005b). The revival of the chora in the late 3rd through the mid-2nd century BC was on a smaller scale. This means that the active phase of Greek land use on the Tarkhankut peninsula spanned no more than $160-170$ years. The agricultural history of the ancient city of Kerkinitis (modern-day Eupatoria), the earliest Greek foundation in western Crimea, appears to have been considerably longer, with an estimate of around 300-350 years of rural settlement. Excavations at the Late-Scythian settlement of Tarpanchi (modern-day village of Okunevka), which revealed a granary with a large deposit of charred grains of wheat and barley (Shcheglov, 1963; Chtcheglov, 1992), testify to a fairly brief, hardly exceeding half a century, period of post-Greek, Scythian, agriculture in the 2nd-1st centuries BC. Medieval nomads and Crimean Tatars held sway over the Steppe Crimea once Greek dominance was on the wain, and it was

Table 1

Description of the studied sites.

\begin{tabular}{|c|c|c|c|c|c|c|c|}
\hline Site & Location & Nearest archaeological site & $\begin{array}{l}\text { Land type in the } \\
\text { second } \\
\text { half of the 20th } \\
\text { century }\end{array}$ & $\begin{array}{l}\text { Modern-day } \\
\text { use }\end{array}$ & $\begin{array}{l}\text { Vegetation } \\
(2011)\end{array}$ & Agrogenesis duration $^{\mathrm{a}}$ & $\begin{array}{l}\text { Position of the } \\
\text { soil in } \\
\text { agrogenic } \\
\text { series }^{\mathrm{a}}\end{array}$ \\
\hline S4 & $\begin{array}{l}5 \mathrm{~km} \text { W of the village } \\
\text { of } \\
\text { Chernomorskoe }\end{array}$ & $\begin{array}{l}\text { Rural settlements of the } 4 \text { th-3rd c. } \\
\text { BC on the periphery of the land } \\
\text { division system }\end{array}$ & Virgin land & Virgin land & Feathergrass $^{\mathrm{b}}$ & $\mathrm{VL}(2500)$ & VL \\
\hline S11 & Cape Tarkhankut & $\begin{array}{l}4.5 \mathrm{~km} \mathrm{SW} \text { of the fortified } \\
\text { farmhouse of Karadzha 3, } \\
\text { 4th-2nd c. BC }\end{array}$ & Virgin land & Virgin land & Steppe grasses & $\mathrm{VL}(2500)$ & VL \\
\hline S12 & v. Olenevka & $\begin{array}{l}0.6 \mathrm{~km} \text { SW of townsite of } \\
\text { Karadzha, 4th c. BC-1st c. AD }\end{array}$ & $\begin{array}{l}\text { Orchard in 19th-20th } \\
\text { cent. }\end{array}$ & Tree nursery & Biota orientalis & $\begin{array}{l}\text { VL( 1800)-CPL( 500)- } \\
\text { MPL(below 188) }\end{array}$ & CPL \\
\hline S15 & $\begin{array}{l}8 \mathrm{~km} \mathrm{~W} \text { of the city } \\
\text { of Eupatoria }\end{array}$ & $\begin{array}{l}3 \mathrm{~km} \mathrm{NW} \text { of Chaika, } 4 \text { th c. BC-1st } \\
\text { c. AD; } 8.5 \mathrm{~km} \mathrm{~W} \text { of Kerkinitis } \\
\text { (6th-2nd c. BC); traces of land } \\
\text { division }\end{array}$ & Arable field & Arable field & Fallow & $\begin{array}{l}\text { CPL(below 600)-PIL( 1950)- } \\
\text { MPL(150-165) }\end{array}$ & CPL \\
\hline S16 & $\begin{array}{l}15 \mathrm{~km} \mathrm{~W} \text { of the city } \\
\text { of Eupatoria }\end{array}$ & $\begin{array}{l}2.5 \mathrm{~km} \mathrm{E} \text { of } \\
\text { Airchi, } 4 \text { th c. BC-1st c. AD; } \\
\text { traces of land division }\end{array}$ & Arable field & Arable field & Winter wheat & $\begin{array}{l}\text { CPL(below 600)-PIL( 1950)- } \\
\text { MPL(150-165) }\end{array}$ & CPL \\
\hline S1 & $\begin{array}{l}1.5 \mathrm{~km} \mathrm{E} \text { of v. } \\
\text { Olenevka }\end{array}$ & $\begin{array}{l}\text { Farmhouses of the } 4 \text { th-3rd c. BC } \\
\text { within the system of land } \\
\text { division }\end{array}$ & Pasture land & Pasture land & $\begin{array}{l}\text { Grasses/ } \\
\text { graminoids }^{\mathrm{b}}\end{array}$ & $\begin{array}{l}\text { VL(>155)-CPL(below 65)- } \\
\operatorname{PIL}(2280)\end{array}$ & PIL \\
\hline S2 & $\begin{array}{l}1.5 \mathrm{~km} \mathrm{E} \text { of v. } \\
\text { Olenevka }\end{array}$ & $\begin{array}{l}\text { Farmhouses of the } 4 \text { th-3rd c. BC } \\
\text { within the system of land } \\
\text { division }\end{array}$ & Pasture land & Pasture land & $\begin{array}{l}\text { Grasses/ } \\
\text { graminoids }^{\mathrm{b}}\end{array}$ & $\begin{array}{l}\text { VL(>155)-CPL(below 65)- } \\
\operatorname{PIL}(2280)\end{array}$ & PIL \\
\hline S14 & $\begin{array}{l}1.5 \mathrm{~km} \mathrm{E} \text { of v. } \\
\text { Olenevka }\end{array}$ & $\begin{array}{l}\text { Farmhouses of the } 4 \text { th-3rd c. BC } \\
\text { within the system of land } \\
\text { division }\end{array}$ & Pasture land & Pasture land & $\begin{array}{l}\text { Grasses/ } \\
\text { graminoids }^{\mathrm{b}}\end{array}$ & $\begin{array}{l}\text { VL(>155)-CPL(below 65)- } \\
\operatorname{PIL}(2280)\end{array}$ & PIL \\
\hline S3 & $\begin{array}{l}5.3 \mathrm{~km} \mathrm{SW} \text { of v. } \\
\text { Chernomorskoe }\end{array}$ & $\begin{array}{l}6.5 \mathrm{~km} \text { NE of Bolshoi Kastel; } \\
\text { rural settlements of the } 4 \text { th-3rd c. } \\
\text { BC on the periphery of the land } \\
\text { division system }\end{array}$ & $\begin{array}{l}\text { Idle (at least in } \\
\text { 1956-1990s) }\end{array}$ & Pasture land & $\begin{array}{l}\text { Feathergrass/ } \\
\text { herbs }^{\text {b }}\end{array}$ & $\begin{array}{l}\mathrm{VL}(>155)-\mathrm{CPL}(>65)- \\
\operatorname{PIL}(<2280)\end{array}$ & PIL \\
\hline S6 & $\begin{array}{l}4.5 \mathrm{~km} \text { W of v. } \\
\text { Krasnaya Polyana }\end{array}$ & $\begin{array}{l}8 \text { km SE of Panksoye II, } \\
\text { 4th-3rd c. BC }\end{array}$ & Arable field & Arable field & Winter wheat & $\mathrm{VL}(>2300)-\mathrm{MPL}(150-165)$ & MPL \\
\hline S7 & $\begin{array}{l}5.5 \mathrm{~km} \mathrm{~S} \text { of v. } \\
\text { Krasnaya Polyana }\end{array}$ & $\begin{array}{l}8.5 \mathrm{~km} \mathrm{~N} \text { of Belyaus, } 4 \text { th c. } \\
\text { BC-1st c. AD }\end{array}$ & Arable field & Arable field & Vetch & $\mathrm{VL}(>2300)-\mathrm{MPL}(150-165)$ & MPL \\
\hline S9 & $\begin{array}{l}4.5 \mathrm{~km} \mathrm{SW} \text { of v. } \\
\text { Mar'ino }\end{array}$ & $\begin{array}{l}1.5 \mathrm{~km} \text { NW of the farmhouse and } \\
\text { land plot at Cape Oirat, } 4 \text { th c. } \\
\text { BC- } 1 \text { st c. AD }\end{array}$ & Arable field & Arable field & Winter wheat & $\mathrm{VL}(>2300)-\mathrm{MPL}(150-165)$ & MPL \\
\hline S5 & $\begin{array}{l}11.3 \mathrm{~km} \text { NE of v. } \\
\text { Chernomorskoe }\end{array}$ & $\begin{array}{l}1.4 \mathrm{~km} \mathrm{~W} \text { of the settlement of } \\
\text { Mezhvodnoe, } 4 \text { th-2nd c. BC }\end{array}$ & $\begin{array}{l}\text { Arable field (1956), } \\
\text { plantage tillage } \\
\text { (1967); } \\
\text { idle since } 1970\end{array}$ & Airfield & $\begin{array}{l}\text { Feathergrass/ } \\
\text { herbs }^{\mathrm{b}}\end{array}$ & $\begin{array}{l}\text { VL(>100)-CPL(below 400)- } \\
\text { PIL( 2000)-MPL( 26)- } \\
\text { MIL(10)- } \\
\text { MPL(1)-MIL(43) }\end{array}$ & MIL (?) \\
\hline S8 & $\begin{array}{l}5 \mathrm{~km} \mathrm{~N} \text { of } \mathrm{v} . \\
\text { Krasnaya Polyana }\end{array}$ & $\begin{array}{l}8.5 \mathrm{~km} \text { E of Panksoye II, 4th-3rd c. } \\
\text { BC }\end{array}$ & $\begin{array}{l}\text { Arable field (1956); } \\
\text { idle since } 1988 .\end{array}$ & $\begin{array}{l}\text { Idle land after } \\
\text { tillage }\end{array}$ & Weeds & $\begin{array}{l}\operatorname{VL}(>2300)-\operatorname{MPL}(\sim 130-140)- \\
\operatorname{MIL}(23)\end{array}$ & MIL \\
\hline S10 & $\begin{array}{l}5 \mathrm{~km} \mathrm{SW} \text { of } \mathrm{v} . \\
\text { Mar'ino }\end{array}$ & $\begin{array}{l}2 \mathrm{~km} \text { NW of the farmhouse and } \\
\text { land plot at Cape Oirat, } 4 \text { th c. } \\
\text { BC-1st c. AD }\end{array}$ & $\begin{array}{l}\text { Arable field (1956); } \\
\text { idle since 1990s }\end{array}$ & $\begin{array}{l}\text { Idle land after } \\
\text { tillage }\end{array}$ & Steppe grasses ${ }^{\mathrm{c}}$ & $\begin{array}{l}\operatorname{VL}(>2300)-\operatorname{MPL}(130-145)- \\
\operatorname{MIL}(20)\end{array}$ & MIL \\
\hline S13 & v. Olenevka & $\begin{array}{l}1 \mathrm{~km} \mathrm{SW} \text { of the townsite of } \\
\text { Karadzha, area of necropolis }\end{array}$ & $\begin{array}{l}\text { Orchard in 19th } \\
\text { cent.; } \\
\text { idle since the early } \\
\text { 20th cent. }\end{array}$ & $\begin{array}{l}\text { Idle land after } \\
\text { orchard plantation }\end{array}$ & Steppe grasses ${ }^{\mathrm{b}, \mathrm{c}}$ & $\begin{array}{l}\text { VL(>2300)-MPL(below 70)- } \\
\operatorname{MIL}(90)\end{array}$ & MIL \\
\hline
\end{tabular}

\footnotetext{
a The components of the agrogenic series of soils are abbreviated as follows: VL - virgin lands; PIL - post-antique idle land; MIL - idle land in the modern era; MPL - modern-day

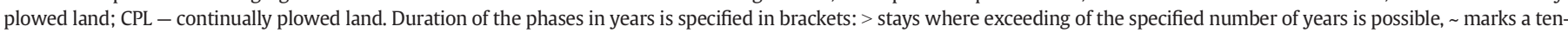

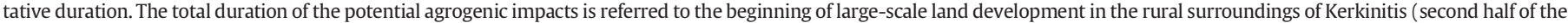
6th century BC); consequently $\mathrm{T}$ is assumed as 2500 years.

b Stipa capillata L.

c Stipa lessingiana Trin. \& Rupr.
} 
not until the beginning of the Russian colonization at the turn of the 18th and 19th centuries that farming again became significant for the region's economy. Based on the local history of agricultural development, the total duration of the current period of land use is estimated to be between $150-165$ years.

\section{Materials and methods}

The main objects of our pedogenetic investigations are presented in Table 1 . This study deploys the method of factor sequences (chronosequences) of agrogenic transformations in soils. In this approach objects are grouped into chronosequences in the way that, while comparing the properties of virgin and/or recently plowed soils, as well as different durations of development and the extent of cultivation (Ivanov and Alexandrovskiy, 1987), one of the factors varies, whereas the others remain constant. Using Jenny's list of soil formation factors (Jenny, 1941) with our additions, the application of the factor chronosequences can be expressed by the formula:

$\left\{\begin{array}{l}\mathrm{S}_{1}=\mathrm{f}\left(\mathrm{C}_{\mathrm{t} 1}, \mathrm{~T}_{\left.(\mathrm{h} 1) \mathrm{cl}, \mathrm{r}, \mathrm{p}, \tau_{\ldots}\right)}\right) \ldots \\ \mathrm{S}_{\mathrm{N}}=\mathrm{f}\left(\mathrm{C}_{\mathrm{tN}}, \mathrm{T}_{(\mathrm{hN}) \mathrm{cl}, \mathrm{r}, \mathrm{p}, \tau \ldots}\right)\end{array}\right.$

where:

$\mathrm{S}_{1 \ldots \mathrm{N}} \quad$ properties of soils in the sequence of agrogenic transformations $(1,2, \ldots \mathrm{N})$;

$\mathrm{T}_{(\mathrm{h} 1 \ldots \mathrm{hN})}$ periods of human activities related to the use of land resources (plowing, irrigation, fertilization, amelioration etc.) or phases of intended or historically determined renaturation (long-term fallow);

$\mathrm{C}_{(\mathrm{t} 1 \ldots \mathrm{tN})}$ successions of natural plant communities and changes of exploited areas chronologically related to periods of human activities;

cl climate;

r topography;

p parent materials;

$\tau \quad$ absolute age of soils.

Time in itself is not a soil-forming factor, but over time the other factors promote pedogenic processes. Estimation of numerical or chronometric age of soil is very difficult but relative dating can be conducted on the basis of chronosequences (Goldberg and MacPhail, 2006). A number of archaeological studies have been attempted at dating cultural phases and specific human activities through maturity or immaturity of buried soils (Goldberg and MacPhail, 2006).

As the studied objects of an agrogenic sequence have been selected within the automorphous areas of the landscape, the influence of water erosion - an essential factor of soil degradation in the steppe zone including the region under study - is thus eliminated.

Our study draws on the concept which defines the part of the soil profile involved in cultivation as a layer, whereas this layer's upper, homogeneous and agronomically valuable part is considered a distinctive genetic horizon (P) (Karavaeva et al., 1985). Soil samples have been taken from three horizons: 1$)$ the upper, most intensively cultivated layer $(0-17(22) \mathrm{cm}) ; 2$ ) underlying layer (the one which underlies the cultivated layer or, in case of idle land, the post-agrogenic layer; usually, 22-40 cm); and 3) parent material (horizon C). In order to facilitate comparison, samples of virgin soils were taken at similar depths.

The agrophysical properties of soils have been evaluated on the basis of their structural composition and wet aggregate stability. The structural composition was evaluated by dry sieving ( 3 replicates). The resulting nine particle size fractions (from $>7$ to $<0.25 \mathrm{~mm}$ ) were used to calculate the total amount of 0.25 to $10 \mathrm{~mm}$ aggregates (STR), the coefficient of structure $\left(\mathrm{K}_{\mathrm{str}}\right.$, a ratio of the mass of structural aggregates of 1-7 $\mathrm{mm}$ to the sum of the aggregates of $<1$ and $>7 \mathrm{~mm}$ ) and cloddiness of the structure (DEFL, a content of structural aggregates of $>1 \mathrm{~mm}$ ). The water-stable aggregates were evaluated by wet sieving (into 6 size fractions, from 5 to $<0.25 \mathrm{~mm}$ ), the results of which were used to calculate the percentage of aggregates measuring $>0.25 \mathrm{~mm}$ $(\Sigma \mathrm{d}>0.25 \mathrm{~mm})$ and weighted average aggregate diameter $(\mathrm{d})$. The coefficient of water stability (W) was determined by Andrianov's (1947) method, which is based on evaluating the amount of aggregates degraded in still water over the 10-min period and employs a sieve covered with filter paper pressed with a ring. The method was replicated 5 times; every time 50 aggregates of each of $5-3,3-2,2-1$, and $1-0.5 \mathrm{~mm}$ fractions were analyzed.

Five parameters enumerated above were used to determine the composite agrophysical parameter of soil (APS), which we suggest may be calculated using the following formula:

APS $=100 \cdot\left(\frac{V_{1}}{V_{1(\mathrm{opt})}} \cdot \frac{V_{2}}{V_{2(\mathrm{opt})}} \cdot \ldots \cdot \frac{V_{\mathrm{n}}}{V_{\mathrm{n}(\mathrm{opt})}}\right)^{\frac{1}{\mathrm{n}}}$,

where:

$\mathrm{V}_{\mathrm{n}}, \mathrm{V}_{\mathrm{n}(\mathrm{opt})}$ actual and optimal values of a specific agrophysical parameter of soil respectively;

$\mathrm{n} \quad$ number of agrophysical parameters of soil.

The plowing exhaustion $\left(D_{\mathrm{p}}, \%\right)$ was determined through the expression:

$\mathrm{D}_{\mathrm{pl}}=100 \cdot\left(\frac{\mathrm{STR}_{\mathrm{b}}-\mathrm{STR}_{\mathrm{t}}}{\mathrm{STR}_{\mathrm{b}}}\right)$

where:

$\mathrm{STR}_{\mathrm{t}}, \mathrm{STR}_{\mathrm{b}}$ total amount of agronomically valuable structural aggregates by dry sieving $(>0.25 \mathrm{~mm})$ in the plowed $(t)$ and underlying (b) horizons (or in the lower layer when idle lands are concerned) respectively.

The soil granulometric index (P, \%) was calculated as the ratio between the amounts of active and passive particles participating in the structural formation, i.e. $\mathrm{P}=100(\mathrm{a} /(\mathrm{b}+\mathrm{c}))$ where $\mathrm{a}$ - particles of $<0.001 \mathrm{~mm}$; b $-0.001-0.005 \mathrm{~mm}$; and c $-0.005-0.05 \mathrm{~mm}$ (Vadyunina and Korchagina, 1961). The total porosity was calculated from the bulk and real densities.

The agrochemical group of indicators included the content of $\mathrm{CO}_{2}$ in carbonates measured by acidometry, bulk nitrogen content as determined by Kjeldahl's procedure, and $\mathrm{pH}_{\mathrm{H}_{2} \mathrm{O}}$.

For evaluation of soil organic matter (SOM), the soil organic carbon (SOC) and labile organic matter were determined and group analysis of humus was conducted (according to Ponomareva and Plotnikova's modification of Tyurin's method). SOM was fractionated into 3 humic acid $\left(C_{h a}\right), 4$ fulvic acid $\left(C_{\mathrm{fa}}\right)$, and base-insoluble fractions. A detailed description of this fractionation method can be found in Ponomareva and Plotnikova (1980) and Slepetiene and Slepetys (2005). The content of available phosphorus and exchangeable potassium was determined by Machigin's method for calcareous soils, using 1\% ammonium carbonate $\left(\left(\mathrm{NH}_{4}\right)_{2} \mathrm{CO}_{3}\right)$ solution (Machigin, 1952; Arinushkina, 1970). In the rare instances of non-carbonated soils, determinations were made by Chirikov's method, using $0.5 \mathrm{M}$ acetic acid $\left(\mathrm{CH}_{3} \mathrm{COOH}\right)$ solution (Arinushkina, 1970).

Bulk chemical composition of the soils and rocks was measured by XRF. The microelement accumulation capability, determined as proposed by Shaw (1964), is a clarke (mass ratio of an element in the Earth's crust) of a group of elements in the soil that acts as an average quantitative estimate of the soil's capability to accumulate the elements, as compared to that of the lithosphere. We use a modification of this 
factor, whereby its total value is determined not as an arithmetical mean but as a geometrical mean value.

The expression for the eluviation coefficient $\left(\mathrm{K}_{\mathrm{e}}\right)$ includes the oxides (Liu et al., 2009) to which we add $\mathrm{MnO}: \mathrm{K}_{\mathrm{e}}=\left(\mathrm{SiO}_{2} /\right.$ $\left.\left(\mathrm{MnO}+\mathrm{CaO}+\mathrm{K}_{2} \mathrm{O}+\mathrm{MgO}+\mathrm{Na}_{2} \mathrm{O}\right)\right)$. Variance analysis of soil properties and cluster analysis by Ward's method in Euclidean space were carried out using STATISTICA software. Soils were classified using the World Reference Base (WRB).

The quality of soils (SQ) of the agrogenic series was evaluated by calculating the geometrical mean value on the basis of the most informative indicators of agrogenesis as proposed by Storie (1978): SQ = $\left(X_{1} \cdot X_{2} \cdot \ldots \cdot X_{n}\right)^{1 / n}$, where $X_{1}, X_{2}, \ldots X_{n}$ are indicators of agrogenesis.

\section{Results and discussion}

\subsection{Character of parent materials}

According to the regionalization scheme of the Crimea developed on the basis of paleogeographical data (Veklich and Sirenko, 1974), uniform western and central parts, which constitute the Black Sea denudation plain, can be distinguished in the composition of the Tarkhankut elevation. The Holocene soil formation was preceded here by the formation of the Black Sea loess horizon when the area was dominated by periglacial semi-desert landscapes with wormwood and saltbush plant communities on loess. Interlayers of thin brown soil suggest, however, certain disruptions in the process of loess formation (Matviishina, 2010; Gerasimenko, 2011). There is also a notable period of loess accumulation at the Pleistocene-Holocene transition (12.8-10.3 ka BP), when the formation of loess did not impede the development of steppes, which are thought to have been more xeric than in the previous period (Matviishina, 2010; Cordova et al., 2011). As loess is in one way or another transformed by soil formation, the loess-like loams and clays of Tarkhankut contain the pedogenic organic matter, geochemical indications of the internal substance migration, etc.

Of the two predominant types of parent material, the loams, usually of a medium and heavy granulometric composition, can be clearly differentiated from limestone eluvium by a more considerable accumulation of $\mathrm{Mn}, \mathrm{Sr}, \mathrm{Zn}, \mathrm{Cu}, \mathrm{Ni}, \mathrm{Cr}, \mathrm{Si}, \mathrm{Pb}$ and $\mathrm{Co}$ (in order of decreasing concentrations) (Table 2). Despite the aforementioned dissimilarity between the two types of parent materials, the extent of their chemical weathering defined as a ratio $\mathrm{Si} /(\mathrm{Al}+\mathrm{Mn}+\mathrm{Fe})$ is identical. This can be explained by the fact that the content of silica is 1.4 times higher in loams than in eluvium of limestones. As suggested by Gerrard (1981), the intensity of chemical weathering can be determined through the molar ratio $\mathrm{CaO} / \mathrm{ZrO}_{2}$, given that the calcium-containing minerals are less resistant to weathering than those containing zirconium. In our case, judging by the ratio $\mathrm{CaO} /$ $\mathrm{ZrO}_{2}$, loam is chemically more transformed than the carbonated eluvium. Thus, these primary properties of the parent materials of the Tarkhankut Peninsula predetermined the genetic differences between the soils which formed on them during the Holocene.

\subsection{Restorative successions of plant communities}

Whenever plowing was abandoned, the adaptive transformation of the structure of the steppe communities during this restorative period occurred syngenetically with the renaturation of soils, which is consistent with the notion of co-evolution of soils and biota and the concept of soils as extended composite phenotypes (Phillips, 2009). As appears from Expression (1), the establishment of chronosequences of the agrogenic soil transformations should take into account that the periods of human activity are chronologically related to successions of natural vegetation and changes of exploited areas. Therefore, factor $C_{t}$ varies over time and space.

The studies of vegetation in agricultural areas of southern Ukraine that were recently abandoned have demonstrated that, by contrast with the active fields, the flora of abandoned fields is replenished with new species, mainly zonal anthropophilic types, that can make-up $20 \%$ of the flora. Meanwhile, the share of the zonal steppe species tripled: from $9 \%$ to $27 \%$ (Bondarenko and Vasil'eva, 2008). In the area we studied, the restorative successions on idle lands of different ages have the structure as the phytomass of the above-ground tier, which is different from that of indigenous communities (Table 3 ).

The ratio of steppe graminoids, that are known to pass from the rhizome gramineous to turf gramineous stage of demutation as the length of the fallowing period increases, is notably larger in the post-antique (Stipa sp., Festuca valesiaca Gaudin, Bromopsis cappadocica (Boiss. \& Balansa) Holub) and modern idle lands (Stipa lessingiana Trin. \& Rupr., Koeleria cristata (L.) Pers.), whereas on virgin lands only one species remains (Stipa capillata $\mathrm{L}$.).

The deposition of above-ground mortmass $(\mathrm{R}+\mathrm{SC})$ depends on the amount of green mass ( $\mathrm{F}$ ) and the mortmass decomposition rate. The more active the production process and the lower the destruction

Table 2

Chemical composition of parent rocks on the Tarkhankut Peninsula (data for Horizon C (cm) of soil profiles - S no. in Fig. 1).

\begin{tabular}{|c|c|c|c|c|c|c|c|c|c|c|c|}
\hline \multirow[t]{2}{*}{ Component } & \multirow[t]{2}{*}{ Unit } & \multicolumn{5}{|c|}{ Loess-like loams ${ }^{\mathrm{a}}$} & \multicolumn{5}{|c|}{ Eluvium of carbonate rocks ${ }^{\mathrm{b}}$} \\
\hline & & S1. 54-58 & S14. 58-60 & S15. 58-60 & S16. 56-58 & Average & S3. $34-40$ & S5. 50-54 & S11. 30-40 & S13. 47-50 & Average \\
\hline $\mathrm{SiO}_{2}$ & $\%$ & 35.2 & 26.4 & 44.7 & 38.6 & $36.2 \pm 3.8$ & 31 & 31.4 & 11.9 & 26.5 & $25.2 \pm 4.6$ \\
\hline $\mathrm{CaO}$ & $\%$ & 19.8 & 17.8 & 18.3 & 11.8 & $16.9 \pm 1.8$ & 28 & 21.4 & 29.7 & 26.9 & $26.5 \pm 1.8$ \\
\hline $\mathrm{Al}_{2} \mathrm{O}_{3}$ & $\%$ & 9 & 6.8 & 10.3 & 9 & $8.8 \pm 0.7$ & 8.7 & 7.9 & 7.1 & 9.4 & $8.3 \pm 0.5$ \\
\hline $\mathrm{Fe}_{2} \mathrm{O}_{3}$ & $\%$ & 2.4 & 3.3 & 2.6 & 3.5 & $3 \pm 0.3$ & 2 & 2.2 & 1.9 & 2.3 & $2.1 \pm 0.1$ \\
\hline $\mathrm{MgO}$ & $\%$ & 2.2 & 2.5 & 2.5 & 2 & $2.3 \pm 0.1$ & 3 & 2.2 & 3.2 & 2.9 & $2.9 \pm 0.2$ \\
\hline $\mathrm{TiO}_{2}$ & $\%$ & 0.5 & 0.6 & 0.6 & 0.7 & $0.6 \pm 0.04$ & 0.4 & 0.6 & 0.4 & 0.5 & $0.5 \pm 0.05$ \\
\hline $\mathrm{Na}_{2} \mathrm{O}$ & $\%$ & 2 & 2.7 & 2.1 & 1.8 & $2.2 \pm 0.2$ & 2.5 & 2 & 2.7 & 2.5 & $2.4 \pm 0.1$ \\
\hline $\mathrm{P}_{2} \mathrm{O}_{5}$ & $\%$ & 0.1 & 0.1 & 0.1 & 0.1 & $0.1 \pm 0$ & 0.1 & 0.2 & 0.3 & 0.2 & $0.2 \pm 0.4$ \\
\hline $\mathrm{K}_{2} \mathrm{O}$ & $\%$ & 1.3 & 1.1 & 1.3 & 1.3 & $1.3 \pm 0.1$ & 1.2 & 1.1 & 1.4 & 1.2 & $1.2 \pm 0.1$ \\
\hline $\mathrm{MnO}$ & ppm & 649.4 & 1042.2 & 1014.6 & 1194.7 & $975.2 \pm 115.6$ & 520.9 & 1222.7 & 430.6 & 722.1 & $724.1 \pm 177.0$ \\
\hline $\mathrm{Sr}$ & $\mathrm{ppm}$ & 278.2 & 434.6 & 215.7 & 282.8 & $302.8 \pm 46.5$ & 212.4 & 227.7 & 237.9 & 242.1 & $230 \pm 6.6$ \\
\hline $\mathrm{Cr}$ & ppm & 79.8 & 103 & 82.2 & 102.7 & $91.9 \pm 6.3$ & 75.3 & 79.7 & 69.3 & 75.5 & $74.9 \pm 2.1$ \\
\hline $\mathrm{Zn}$ & ppm & 65.5 & 115.5 & 68.8 & 106.5 & $89.1 \pm 12.8$ & 65.3 & 61.4 & 68.5 & 73.8 & $67.2 \pm 2.6$ \\
\hline $\mathrm{Ni}$ & ppm & 36.9 & 67 & 42.3 & 62.6 & $52.2 \pm 7.4$ & 33.3 & 36 & 32.9 & 37.2 & $34.8 \pm 1.0$ \\
\hline $\mathrm{Cu}$ & ppm & 23.2 & 44.5 & 30.4 & 54.5 & $38.1 \pm 7.0$ & 15 & 22.6 & 14.9 & 23.2 & $18.9 \pm 2.3$ \\
\hline $\mathrm{Pb}$ & ppm & 16.6 & 26.6 & 15.4 & 28.2 & $21.7 \pm 3.3$ & 8.8 & 11.7 & 12.7 & 10.7 & $11 \pm 0.8$ \\
\hline Co & ppm & 11.2 & 12.1 & 13.3 & 20.3 & $14.2 \pm 2.1$ & 6.2 & 11.4 & 3.3 & 7.8 & $7.2 \pm 1.7$ \\
\hline V & $\mathrm{ppm}$ & 60.6 & 60.6 & 64.9 & 74.7 & $65.2 \pm 3.3$ & 53.4 & 56.7 & 46.8 & 57.1 & $53.5 \pm 2.4$ \\
\hline As & ppm & 6.2 & 5.6 & 7.4 & 7.3 & $6.6 \pm 0.4$ & 7.2 & 8.7 & 4.5 & 7.2 & $6.9 \pm 0.9$ \\
\hline $\mathrm{Zr}$ & ppm & 249.8 & 251 & 246.2 & 280.4 & $256.8 \pm 7.9$ & 215.8 & 293.9 & 219.7 & 222.4 & $237.9 \pm 18.7$ \\
\hline
\end{tabular}

\footnotetext{
a This type of parent material is also characteristic of sites: S2, S6, S7, S9, S10 and S12.
}

b This type of parent material is also characteristic of sites: S4 and S8. 
Table 3

Structure of phytomass of the above-ground tier under conditions of virgin and idle lands.

\begin{tabular}{|c|c|c|c|c|c|c|c|c|}
\hline \multirow[t]{2}{*}{$\begin{array}{l}\text { Site } \\
\text { number }^{\mathrm{a}}\end{array}$} & \multirow{2}{*}{$\begin{array}{l}\text { Type } \\
\text { of } \\
\text { land }^{b}\end{array}$} & \multirow[t]{2}{*}{$\begin{array}{l}\mathrm{H}, \\
\mathrm{cm}\end{array}$} & \multirow[t]{2}{*}{$\begin{array}{l}\mathrm{TPC}, \\
\%\end{array}$} & \multirow{2}{*}{$\begin{array}{l}\text { Number of } \\
\text { plant } \\
\text { species }\end{array}$} & \multirow[t]{2}{*}{$\begin{array}{l}\text { Composition } \\
\text { of herbage }\end{array}$} & \multicolumn{3}{|c|}{$\begin{array}{l}\text { Mass of dry substance, } \\
\mathrm{g} \mathrm{m}^{-2}\end{array}$} \\
\hline & & & & & & $F$ & $R$ & SC \\
\hline $\mathrm{C} 1$ & VL & 36 & 75 & 17 & $1+2+14$ & 159.16 & 254.52 & 182.00 \\
\hline $\mathrm{C} 2$ & PIL & 32 & 95 & 12 & $4+2+6$ & 85.56 & 181.68 & 112.04 \\
\hline $\mathrm{C} 3$ & MIL & 29 & 70 & 12 & $2+1+9$ & 118.88 & 117.56 & 61.00 \\
\hline
\end{tabular}

Abbreviations: $\mathrm{H}$ - height of herbage; TPC - total projective cover; $\mathrm{F}$ - green phytomass; $\mathrm{R}$ - plant debris; $\mathrm{SC}$ - litter.

a Locations of the sites are shown in Fig. 1.

b See Table 1 , note a, for abbreviations.

c The numbers specify respectively graminoids + legumes + herbs.

rate, the larger the accumulation of the above-ground mortmass. In the conditions studied, the maximum amount of above-ground mortmass has been recorded in virgin lands $\left(436 \mathrm{~g} \mathrm{~m}^{-2}\right.$ ), while in idle lands it decreases. Values for idle lands of the modern era are 1.6 times lower than for the post-antique idle lands. The ratio $(\mathrm{R}+\mathrm{SC}) / \mathrm{F}$ reflects the relationship between the specific rates of the plant-substance accumulation and destruction processes. On virgin lands, all the structural elements of the above-ground phytomass (i.e. F, R and SC) have the highest values, while for post-antique idle lands, the above-ground mortmass accumulates most actively and the amount of the growing green mass is lower. It seems that in the idle lands of the modern era the destruction of plant substance occurs more intensively.

The comparison with indigenous communities has demonstrated that the differences in the edification structure of restored vegetation remain noticeable even after 16-35 centuries of development (Lisetskii, 1998). Thus, the duration of a succession does not smooth away the dissimilarities in productivity caused by the ontogenetic maturity of soils.

\subsection{Character of soil diversity}

The soil cover of the Tarkhankut Peninsula is fairly diverse (Fig. 1), the predominant types being Calcic Chernozems and Rendzic Leptosols (Table 4). In terms of the fine-earth thickness, i.e. the distance from the top surface down to the roof of the solid bed rocks, Calcic Chernozems are characterized by a thick profile, while soils on limestone eluvia are medium- or weakly developed. The limestone eluvium, which serves as parent material for Rendzic Leptosols, contains 19-20 mass percent of detritus, of which over $50 \%$ exceed $7 \mathrm{~mm}$ in diameter. Therefore, all the soils formed on this kind of parent material are, to a greater or lesser extent, rich in detritus. In the majority of the peninsula's soils, carbonates are present already in the topsoil layer. The upper soil horizon's

Table 4

Reference soil profiles on the Tarkhankut Peninsula.

\begin{tabular}{lllll}
\hline Section & $\begin{array}{l}\text { A.s.l. } \\
(\mathrm{m})\end{array}$ & $\begin{array}{l}\text { Soil } \\
\text { code }^{\mathrm{b}}\end{array}$ & $\begin{array}{l}\text { Structure of the profile: } \\
\text { horizons }\end{array}$ & $\begin{array}{l}\text { Horizon } \\
\text { thickness } \\
(\mathrm{cm})\end{array}$
\end{tabular}

Abbreviations: A.s.l. - altitude above sea level.

a For locations of the sections, see Fig. 1.

b Soil codes correspond to nos. in Fig. 1 .

c Depth to effervescence with $10 \% \mathrm{HCl}$. color is brown of varying intensity. The soils that have formed on the weathering products of carbonate rocks tend to be lighter.

Physicochemical properties of soils in reference sections P1-P4 (Table 5) make it possible to identify the main differences between the dominant soils of Tarkhankut. Calcic Chernozems on loess-like loams are dark brown in their humus-accumulative horizon. They are characterized by an alkaline reaction of the soil solution and a gentle decrease of humus content down the profile; soil effervescence starts at a depth of $70 \mathrm{~cm}$ with impregnation with carbonates found only in horizon BC $(73-105 \mathrm{~cm})$; the biological accumulation of phosphorus is recorded in the uppermost $30-\mathrm{cm}$ thick stratum. Calcic Chernozems with secondary carbonates differ from the above by having a shorter profile and the presence of carbonates throughout the profile, as well as the accumulation of mobile phosphates in the lower section of the profile. Petrocalcic Chernozems have a medium-thick profile strongly impregnated with carbonates which act as a geochemical barrier. Rendzic Leptosols on limestone eluvia, at a depth of $40-55 \mathrm{~cm}$, lie on a shield of limestone.

\subsection{Properties of soils of the agrogenic series}

Soil, like any self-organizing natural system, undergoes certain fluctuating processes and changes of state as well as several stages of irreversible development including generation, formation and destruction. Anthropogenic soil formation is a complex and controversial process where, due to acceleration, deceleration and distortion of elemental soil processes, their combination occurs. In terms of their impact on fertility, these processes can be divided into the progressive, pseudo-progressive (determined by a phenomenon such as the allopseudomorphosis (Lisetskii, 2008)) and degradative, among which thirteen (Krupenikov, 2005) to forty types of degradation are now distinguished. Correspondingly, also man-made soils register these changes, and, in the case of slow irreversible processes they also 'memorize' them as either positive or negative soil properties. In soil, as an ecosystem, processes of a characteristically long duration (i.e. the time interval required for a certain process to attain a relative equilibrium with natural factors) can be considered an accumulation of residual properties of processes of shorter characteristic duration.

\subsubsection{Agrophysical properties}

Granulometrically, the studied soils can mainly be defined as loamy (clay content $<27 \%$ ) (Table 6 ). The broad variation range of the structural property indicator $(\mathrm{P})$ is explained by the differences in the ratio between the amounts of active, binding particles and passive particles, which participate in the structural formation as passive material. The higher the P value, the greater the structuring ability of the soil. As can be seen in Table 6 , soils of the agrogenic series (virgin and postantique long-term fallow lands) are characterized by low P values.

The set of indicators selected for characterization of the agrophysical condition of soils facilitates evaluation of the differences between soils through their anti-erosion and anti-deflation stability and structure, which results from cultivation or bioturbations. While using Expression (2), the establishment of an optimal value of a particular indicator is of importance. Traditionally, the virgin soil is taken as a reference. However, a number of agrophysical parameters of a soil do not change unidirectionally over the course of its natural and agrogenic evolution. The virgin soils differ in having the maximum values of coefficient $\mathrm{W}$, which expresses the water stability of soil aggregates of all dimensions during their humidification and thus is diagnostic of the soils' stability against water erosion. The soils of the post-antique idle lands exceed the other soils in indicator $\mathrm{d}$, which characterizes the agronomic importance of water-stable aggregates through their diameter and mass (Bulygin and Nearing, 1999). In the fields that only recently have been cultivated the cloddiness of the structure, which determines the soil resistivity to wind erosion, can be successfully regulated by means of the mechanical working - an advantage the continually plowed lands do 
Table 5

Physicochemical properties of soils from reference sections on the Tarkhankut Peninsula.

\begin{tabular}{|c|c|c|c|c|c|c|c|c|c|}
\hline \multirow[t]{2}{*}{ Section } & \multirow[t]{2}{*}{ Depth $(\mathrm{cm})$} & \multirow[t]{2}{*}{ Munsell color (dry) } & \multirow[t]{2}{*}{ Bulk density $\left(\mathrm{g} \mathrm{cm}^{-3}\right)$} & \multicolumn{2}{|c|}{$\begin{array}{l}\text { Sum of particles } \\
(\mathrm{mm}) \text { in } \%\end{array}$} & \multirow[t]{2}{*}{$\mathrm{pH}$} & \multirow[t]{2}{*}{$\mathrm{CaCO}_{3}(\%)$} & \multirow[t]{2}{*}{ SOM (\%) } & \multirow[t]{2}{*}{$\mathrm{P}_{2} \mathrm{O}_{5}{ }^{\mathrm{a}}\left(\mathrm{mg} \mathrm{kg}^{-1}\right)$} \\
\hline & & & & $<0.01$ & $<0.001$ & & & & \\
\hline \multirow[t]{7}{*}{ P1 } & $0-12$ & 10YR3/3 & 0.97 & 60.32 & 37.44 & 8.07 & 0 & 3.44 & 8.09 \\
\hline & $12-32$ & 10YR3/3 & 1.24 & 60.32 & 41.60 & 7.98 & 0 & 3.00 & 8.49 \\
\hline & $32-54$ & 7.5YR3/4 & 1.36 & 58.24 & 41.60 & 8.01 & 0 & 2.50 & 1.68 \\
\hline & $54-73$ & $7.5 Y R 4 / 4$ & 1.30 & 58.24 & 39.52 & 8.20 & 0 & 2.12 & 4.25 \\
\hline & $73-105$ & 7.5YR5/4 & 1.31 & 61.80 & 35.02 & 8.54 & 13.55 & 1.59 & 1.22 \\
\hline & $105-248$ & 7.5YR6/4 & 1.29 & 61.80 & 35.02 & 8.60 & 13.55 & 1.06 & 2.38 \\
\hline & $248+$ & 7.5YR6/4 & - & - & - & 9.03 & 19.46 & 0.74 & 3.27 \\
\hline \multirow[t]{5}{*}{ P2 } & $0-51$ & 10YR5/3 & 1.01 & 59.80 & 24.72 & 8.75 & 18.39 & 3.61 & 4.37 \\
\hline & $51-67$ & 10YR5/4 & 1.29 & 57.68 & 28.84 & 9.08 & 21.92 & 2.27 & 3.95 \\
\hline & $67-108$ & 10YR5/4 & 1.16 & 61.8 & 35.02 & 8.70 & 27.40 & 1.73 & 3.59 \\
\hline & $108-145$ & 10YR7/4 & 1.28 & 65.92 & 32.96 & 8.61 & 25.81 & 0.89 & 9.49 \\
\hline & $145+$ & 10YR7/4 & 1.30 & 63.48 & 32.28 & 8.58 & 25.64 & 1.21 & 19.88 \\
\hline \multirow[t]{3}{*}{ P3 } & $0-23$ & 10YR5/2 & 1.29 & 20.20 & 8.08 & 8.73 & 47.61 & 4.72 & 15.77 \\
\hline & $23-49$ & 10YR5/3 & 1.18 & 32.30 & 12.10 & 8.30 & 44.34 & 3.36 & 9.53 \\
\hline & $49-73$ & 10YR7/3 & 1.24 & 36.34 & 14.15 & 8.15 & 50.36 & 2.13 & 9.47 \\
\hline \multirow[t]{2}{*}{ P4 } & $0-36$ & 10YR5/3 & 1.07 & 20.21 & 4.05 & 8.37 & 36.06 & 4.25 & 5.23 \\
\hline & $36-48$ & 10YR5/2 & 1.08 & 20.20 & 8.07 & 8.38 & 49.92 & 3.55 & 4.98 \\
\hline
\end{tabular}

a By Machigin's method.

not have. Therefore, the optimal values of agrophysical indicators were determined through a stable regularity of maximum values found in a particular group of soils of the agrogenic series. To calculate APS using Eq. (2), an optimal value of specific parameters of soil was calculated as a mean of the three maximum values of this parameter within the sequence of agrogenic transformations in soils: coefficient of water stability (W) for virgin lands; the average weighted diameter of water-stable aggregates and $\Sigma d>0.25 \mathrm{~mm}$ for post-antique idle lands; the coefficient

Table 6

Physical properties of agrogenic (post-agrogenic) and underlying horizons of soils of the agrogenic series.

\begin{tabular}{|c|c|c|c|c|c|c|c|c|}
\hline \multirow[t]{2}{*}{ Site } & \multirow[t]{2}{*}{ Depth $(\mathrm{cm})$} & \multirow[t]{2}{*}{ Munsell color (dry) } & \multirow[t]{2}{*}{ Bulk density $\left(\mathrm{g} \mathrm{cm}^{-3}\right)$} & \multirow[t]{2}{*}{ Real density $\left(\mathrm{g} \mathrm{cm}^{-3}\right)$} & \multirow[t]{2}{*}{ Total porosity (\%) } & \multirow[t]{2}{*}{$\begin{array}{l}\text { Indicator of structural } \\
\text { properties }(\mathrm{P}, \%)\end{array}$} & \multicolumn{2}{|c|}{$\begin{array}{l}\text { Sum of particles } \\
(\mathrm{mm})\end{array}$} \\
\hline & & & & & & & $<0.01$ & $<0.001$ \\
\hline \multicolumn{9}{|c|}{ Virgin land } \\
\hline S4 & $0-24$ & 10YR6/2 & 1.05 & 2.47 & 57.49 & 32 & 20.60 & 7.88 \\
\hline S11-1 & $0-24$ & 10YR7/3 & 1.11 & 2.48 & 55.24 & 22 & 22.44 & 8.36 \\
\hline S11-2 & $24-32$ & 10YR6/6 & - & 2.35 & & 20 & 25.70 & 9.90 \\
\hline S11-3 & $32-34$ & 10YR7/6 & & 2.58 & & - & 16.58 & 7.27 \\
\hline \multicolumn{9}{|c|}{ Continually plowed land } \\
\hline S12 & $0-22$ & 2.5YR5/4 & - & 2.66 & & 38 & 35.58 & 15.58 \\
\hline S15-1 & $0-17$ & 10YR5/3 & 1.03 & 2.32 & 55.60 & 51 & 38.27 & 14.35 \\
\hline S15-2 & $17-27$ & 10YR5/3 & 1.11 & 2.30 & 51.74 & 89 & 47.67 & 24.78 \\
\hline S15-3 & $27-54$ & 10YR5/3 & - & - & & - & - & - \\
\hline S16-1 & $0-10$ & 10YR5/3 & 1.14 & 2.31 & 50.65 & 74 & 54.18 & 25.41 \\
\hline S16-2 & $10-23$ & 10YR4/3.5 & 1.33 & 2.38 & 44.12 & 148 & 47.46 & 29.82 \\
\hline S16-3 & $23-35$ & 10YR4.5/3 & - & - & & & - & \\
\hline \multicolumn{9}{|c|}{ Post-antique long-term fallow land } \\
\hline S1-1 & $0-17$ & 10YR5/4 & 1.15 & 2.35 & 51.06 & 26 & 30.78 & 14.56 \\
\hline S1-2 & $17-21$ & 10YR5/3 & 1.15 & 2.43 & 52.67 & 19 & 44.54 & 11.76 \\
\hline S1-3 & $21-33$ & 10YR5/3 & 1.30 & - & & - & - & - \\
\hline S3-1 & $0-17$ & 10YR5/3 & 1.09 & 2.34 & 53.42 & 37 & 33.58 & 16.07 \\
\hline S3-2 & $17-34$ & 10YR5/3 & 1.23 & 2.49 & 50.60 & 54 & 33.57 & 23.09 \\
\hline S14-1 & $0-15$ & 10YR5/3 & 1.04 & 2.25 & 53.78 & 49 & 41.20 & 15.45 \\
\hline S14-2 & $15-27$ & 10YR5/3 & 1.02 & 2.27 & 55.07 & 36 & 43.88 & 17.10 \\
\hline \multicolumn{9}{|c|}{ Modern-day plowed land } \\
\hline S6-1 & $0-12$ & 10YR4/2 & 0.89 & 2.44 & 63.52 & 34 & 58.59 & 24.36 \\
\hline S6-2 & $12-20$ & 10YR4/2 & 1.26 & 2.41 & 47.72 & 65 & 55.12 & 36.89 \\
\hline S7-1 & $0-17$ & 10YR4/2 & 0.96 & 2.54 & 62.20 & 140 & 48.93 & 38.22 \\
\hline S7-2 & $17-26$ & 10YR3/3 & 1.10 & 2.66 & 58.65 & 104 & 52.50 & 32.13 \\
\hline S9-1 & $0-14$ & 10YR6/3.5 & 0.88 & 2.49 & 64.66 & 80 & 24.44 & 14.14 \\
\hline S9-2 & $14-21$ & 10YR5/3 & 1.18 & 2.62 & 54.96 & 95 & 45.91 & 24.48 \\
\hline \multicolumn{9}{|c|}{ Long-term fallow land in the modern era } \\
\hline S5-1 & $0-22$ & 10YR5/3 & 1.12 & 2.49 & 55.02 & 33 & 38.06 & 19.97 \\
\hline S5-2 & $22-46$ & 10YR5/3 & 1.28 & 2.56 & 50.00 & 34 & 38.43 & 20.79 \\
\hline S8-1 & $0-9$ & $10 Y R 3 / 3$ & 0.93 & 2.69 & 65.43 & 29 & 37.37 & 14.95 \\
\hline S8-2 & $9-22$ & 10YR4/2 & 1.19 & 2.75 & 56.73 & 57 & 32.12 & 15.35 \\
\hline S10-1 & $0-13$ & 10YR5/4 & 1.01 & 2.55 & 60.39 & 54 & 37.57 & 16.36 \\
\hline S10-2 & $13-24$ & 10YR5/5 & 1.24 & 2.64 & 53.03 & 53 & 42.84 & 22.64 \\
\hline S13-1 & $0-17$ & 7.5YR5/4 & 1.13 & 2.22 & 49.10 & 31 & 26.52 & 13.87 \\
\hline S13-2 & $17-31$ & 10YR4/5 & - & 2.24 & & 42 & 30.19 & 14.28 \\
\hline
\end{tabular}


Table 7

Physical properties of soils of the agrogenic series.

\begin{tabular}{|c|c|c|c|c|c|c|c|}
\hline Site $^{\mathrm{a}}$ & $\mathrm{K}_{\mathrm{str}}$ & DEFL $(\%)$ & $\Sigma \mathrm{d}>0.25 \mathrm{~mm}(\%)$ & $\mathrm{d}(\mathrm{mm})$ & W & APS & $\mathrm{D}_{\mathrm{pl}}(\%)$ \\
\hline \multicolumn{8}{|c|}{ Virgin land $(V L)$} \\
\hline S4 & 1.16 & 59.5 & 54.35 & 0.89 & 92.9 & 6.00 & 0 \\
\hline S11 & 0.81 & 54.5 & 41.62 & 0.75 & 90.4 & 2.66 & 0 \\
\hline \multicolumn{8}{|c|}{ Continually plowed land (CPL) } \\
\hline S12-1 & 0.92 & 72.8 & 28.81 & 0.44 & 65.1 & 1.18 & \\
\hline S15-1 & 0.72 & 55.4 & 29.75 & 0.38 & 68.7 & 0.66 & 8.4 \\
\hline S15-2 & 1.09 & 74.9 & 28.07 & 0.38 & 62.3 & 1.16 & \\
\hline S16-1 & 1.35 & 74.3 & 22.43 & 0.25 & 25.7 & 0.31 & 4.4 \\
\hline S16-2 & 1.10 & 81.5 & 39.83 & 0.34 & 22.1 & 0.57 & \\
\hline \multicolumn{8}{|c|}{ Post-antique idle land (PIL) } \\
\hline S1-1 & 1.15 & 67.2 & 47.94 & 0.78 & 87.1 & 5.37 & -1.6 \\
\hline S1-2 & 1.30 & 67.5 & 43.04 & 0.86 & 84.8 & 5.87 & \\
\hline S3-1 & 1.33 & 65.7 & 54.85 & 1.11 & 89.1 & 9.21 & 0.04 \\
\hline S3-2 & 1.74 & 71.9 & 40.97 & 0.80 & 84.5 & 7.25 & \\
\hline S14-1 & 1.11 & 59.8 & 47.08 & 1.73 & 89.3 & 8.21 & 1.5 \\
\hline S14-2 & 1.66 & 68.7 & 45.79 & 1.29 & 87.4 & 12.56 & \\
\hline \multicolumn{8}{|c|}{ Modern-day plowed land (MPL) } \\
\hline S6-1 & 0.79 & 66.2 & 23.40 & 0.23 & 19.6 & 0.12 & 2.0 \\
\hline S6-2 & 1.29 & 84.5 & 28.80 & 0.38 & 25.5 & 0.65 & \\
\hline S7-1 & 0.80 & 87.6 & 21.97 & 0.29 & 35.3 & 0.33 & 0.01 \\
\hline S7-2 & 0.80 & 88.7 & 42.62 & 0.56 & 57.4 & 2.03 & \\
\hline S9-1 & 0.79 & 71.7 & 23.90 & 0.30 & 24.9 & 0.22 & 3.0 \\
\hline S9-2 & 1.26 & 78.1 & 28.07 & 0.42 & 41.2 & 1.02 & \\
\hline \multicolumn{8}{|c|}{ Idle land in the modern era (MIL) } \\
\hline S5-1 & 2.16 & 81.6 & 44.94 & 0.97 & 79.6 & 10.31 & -1.0 \\
\hline S5-2 & 1.69 & 80.8 & 42.04 & 0.75 & 65.2 & 5.98 & \\
\hline S8-1 & 1.10 & 67.8 & 37.69 & 0.51 & 73.7 & 2.25 & 1.6 \\
\hline S8-2 & 1.27 & 85.1 & 39.53 & 0.79 & 80.1 & 5.77 & \\
\hline S10-1 & 0.92 & 66.7 & 32.83 & 0.63 & 79.6 & 2.15 & 1.7 \\
\hline S10-2 & 0.62 & 76.4 & 37.75 & 0.65 & 76.9 & 1.91 & \\
\hline S13-1 & 0.77 & 59.6 & 30.84 & 0.52 & 88.6 & 1.39 & 3.0 \\
\hline S13-2 & 0.88 & 65.9 & 36.85 & 0.50 & 83.6 & 1.91 & \\
\hline
\end{tabular}

Abbreviations: $\mathrm{K}_{\mathrm{str}}$ - coefficient of structural properties; DEFL - cloddiness of the structure; $\Sigma \mathrm{d}>0.25 \mathrm{~mm}$ - percentage of water-stable aggregates measuring $>0.25 \mathrm{~mm}$; $\mathrm{d}$ - weighted average diameter of water-stable aggregates; $\mathrm{W}-$ coefficient of water stability, according to Andrianov; APS - agrophysical index of soil; $\mathrm{D}_{\mathrm{pl}}$ - plowing exhaustion.

a Numerals 1 and 2 stay for horizons: 1 - upper, most exposed to mechanical cultivation; 2 - underlying (either the horizon underlying the plow zone or post-agrogenic [for idle lands]).

of structure for idle lands in the modern era; cloddiness of the structure (DEFL) for modern-day plowed lands. The calculations of the composite agrophysical soil indicator using Expression (2) and the data from Table 7 have demonstrated that according to their mean values of APS, i.e. their agrophysical quality, soils form the following decreasing sequence: post-antique idle land (8.1) - virgin land (4.3) - idle land in the modern era (4.0) - continually plowed lands (1.0) - modern-day plowed lands (0.7). The positive effect of previous cultivation on agrophysical qualities of dry-steppe soils has already been demonstrated in a study of soils in the rural territory of the ancient Greek city of Olbia (Lisetskii, 2008).

Based on the stratum-by-stratum data on the physical properties of soils (Table 7), the plowing exhaustion of the upper soil horizon $A\left(D_{p l}\right)$ was calculated to vary from 1 to $8 \%$. The $D_{\mathrm{pl}}$ value (\%) calculated through Expression (3) may be interpreted in two different ways depending on the soil condition. When the soil's total humic horizon is thicker than $40 \mathrm{~cm}$ and the soil has been continually cultivated (to the depth of $20-22 \mathrm{~cm}$ ), the increase of the $\mathrm{D}_{\mathrm{pl}}$ value is diagnostic of the extent of degradation (abrasion) of agronomically valuable structural elements in the plow zone as compared to the underlying horizon. The soils that only have been cultivated more recently and not exhausted by plowing will have $D_{p l}$ values close to zero. The values of $D_{p l}$ can, however, also be negative, as, for example, in idle lands, since the soil's structural properties refurbish faster in the upper rather than lower layers. In such case, the $\mathrm{D}_{\mathrm{pl}}$ index is indicative of the degree of functional soil renaturation. According to the data presented in Table 7, the plowing exhaustion of the continually plowed lands is twice as high compared to the modern-day plowed lands, and the post-antique idle lands are close to virgin lands, while in the idle lands of the modern era, the lower parts (usually deeper than 13(17) $-22 \mathrm{~cm}$ ) of the plow zone still retain traces of agricultural stresses in their soil structure.

In regions with combined water and wind erosion it is not only the structural condition that is important for the evaluation of the agrophysical condition of soils, but also the protective properties of the soil. These can reveal themselves under the action of a destructive agent and are conditioned by the combination of physicochemical properties (SOM and its quality, ratio of Ca in the absorbing complex, carbonate content in the soils etc.) The agrophysical condition of soils, in our opinion, is best expressed through the composite agrophysical soil indicator (APS) proposed here, which in the integral evaluation takes into account the limiting (most sensitive) factor.

\subsubsection{Chemical properties and composition of SOM}

In natural steppe Chernozems, due to the biological accumulation of phosphorus during the Holocene, the relative content of $\mathrm{P}_{2} \mathrm{O}_{5}$ in horizon A was $22 \%$ higher in the lower layers of soil. Meanwhile, the amount of mobile phosphates in the accumulative horizon increased 4.5 fold over the first 2000 years of the natural soil formation (Lisetskii and Ergina, 2010). In the agrocenoses 'biopumping' of phosphorus into the upper soil horizons diminishes as a result of harvesting.

Virgin lands and idle lands of the modern era contain small and medium amounts (10-30 $\mathrm{mg} \mathrm{kg}^{-1}$ ) of mobile phosphates (Table 8), and represent the soils with the smallest value in the post-antique idle lands $\left(9-10 \mathrm{mg} \mathrm{kg}^{-1}\right)$. Due to the retention of the previously applied phosphate fertilizers, the content of phosphates in the modern-day plowed lands is high ( $>30 \mathrm{mg} \mathrm{kg}^{-1}$ ), and in the continually plowed lands very high ( $>70 \mathrm{mg} \mathrm{kg}^{-1}$ ).

According to the scale generally accepted in agrochemistry (Arinushkina, 1970), all soils of the agrogenic series have a high content of exchangeable potassium $-300-400 \mathrm{mg} \mathrm{kg}^{-1}$ (Table 8). The content of $\mathrm{K}_{2} \mathrm{O}$, however, is very high in all arable soils $\left(>400 \mathrm{mg} \mathrm{kg}^{-1}\right)$, being only slightly lower than in virgin lands. According to this criterion, idle lands of different periods do not differ much from each other.

In idle lands and currently cultivated soils, the share of exchangeable calcium in the absorbing complex of the upper horizon amounts to $88-89 \%$. In continually plowed and virgin soils, due to decalcination, this value is lower amounting to $83 \%$ and $78 \%$ respectively.

The data in Table 5 demonstrate that virgin soils (P2-P4) contain from 3.4 to $4.6 \%$ of SOM in horizon A. The study of soils in the rural territory of the ancient city of Olbia showed that continually plowed lands had lost $46 \%$ of organic matter, while the newly developed soils cultivated over the last $100-130$ years only $44 \%$ (Lisetskii, 2008). The present study shows that the loss of carbon in the continually plowed soils amounts to $51 \%$ C, in the modern-day plowed soils - to $39 \%$, in the idle lands of the modern era - to $32 \%$ and in the post-antique idle lands - to $27 \%$, as compared to the $C$ content in the $0-23 \mathrm{~cm}$ layer of virgin soils (P3 in Table 5). The loss of humus impacts the agrophysical properties of soils, since the binding of microaggregates into macroaggregates occurs during the coagulation of finely dispersed elementary soil particles, which involves $C$ and polyvalent cations. The favorable physical and chemical properties of the steppe and the forest soils are exclusively associated with the high concentration of organic matter (Miralles et al., 2009).

Natural soils are characterized by the humate type $\left(\mathrm{C}_{\mathrm{ha}} / \mathrm{C}_{\mathrm{fa}}=\right.$ 1.5-2.0), with humus being very rich in nitrogen. The idle-land soils, regardless of the duration of the fallowing regime, are the closest to virgin soils in terms of the $\mathrm{N}$ content in humus. The high $\mathrm{N}$ ratio (Orlov et al., 2004) is also characteristic of the continually plowed soils. In the newly developed plowed soils the $\mathrm{C}$ : $\mathrm{N}$ value is between 8-14 (i.e. middle to low).

In terms of the humification rate of SOM in the soils of the agrogenic series, which can be calculated as $\left(C_{\mathrm{ha}} / \mathrm{C}\right) / 100 \%$ (Orlov et al., 2004), the 
Table 8

Chemical properties and state of humus of soils of the agrogenic series.

\begin{tabular}{|c|c|c|c|c|c|c|c|c|c|c|c|c|c|}
\hline \multirow[t]{2}{*}{ Site } & \multirow[t]{2}{*}{$\mathrm{pH}_{\mathrm{H}_{2} \mathrm{O}}$} & \multirow[t]{2}{*}{$\mathrm{CaCO}_{3}, \%$} & \multicolumn{3}{|c|}{$\begin{array}{l}\text { Exchange bases, mmol } \\
\text { (equiv.)/100 g }\end{array}$} & \multirow{2}{*}{\multicolumn{2}{|c|}{$\begin{array}{l}\mathrm{P}_{2} \mathrm{O}_{5} \\
\frac{\mathrm{K}_{2} \mathrm{O}}{\mathrm{mg} / \mathrm{kg} \text { (Machigin method) }}\end{array}$}} & \multirow[t]{2}{*}{ C, \% } & \multirow[t]{2}{*}{$\mathrm{C}_{\mathrm{ha}}: \mathrm{C}, \%$} & \multirow[t]{2}{*}{$\mathrm{C}_{\mathrm{ha}}: \mathrm{C}_{\mathrm{fa}}$} & \multirow[t]{2}{*}{$\mathrm{N}_{\text {bulk}} \%$} & \multirow[t]{2}{*}{$\mathrm{C}: \mathrm{N}$} & \multirow[t]{2}{*}{$\mathrm{C}_{\text {labile }} / \mathrm{C}, \%$} \\
\hline & & & $\mathrm{Ca}^{++}$ & $\mathrm{Mg}^{++}$ & $\mathrm{Na}^{+}$ & & & & & & & & \\
\hline \multicolumn{14}{|c|}{ Virgin land } \\
\hline S4 & 8.1 & 63.3 & 7.2 & 1.4 & 0.5 & 17.4 & 539.6 & 2.08 & 26.6 & 1.1 & 0.225 & 5.1 & 9.3 \\
\hline S11-1 & 8.3 & 59.5 & 10.2 & 2.2 & 0.8 & 11.7 & 458.4 & 1.94 & 11.3 & 0.6 & 0.213 & 9.4 & 5.6 \\
\hline S11-2 & 8.6 & 60.9 & 5.9 & 2.0 & 2.0 & 6.2 & 615.6 & 1.39 & 9.1 & 0.6 & 0.218 & 7.8 & 5.5 \\
\hline \multicolumn{14}{|c|}{ Continually plowed land } \\
\hline S12 & 8.2 & 27.9 & 13.3 & 3.9 & 1.0 & 69.9 & 349.4 & 1.36 & 15.6 & 1.7 & 0.233 & 7.0 & 5.0 \\
\hline S15-1 & 8.1 & 24.5 & 17.4 & 2.9 & 0.1 & 110.3 & 463.1 & 1.33 & 22.7 & 2.1 & 0.195 & 5.7 & 5.8 \\
\hline S15-2 & 8.2 & 24.8 & 12.7 & 3.4 & 0.3 & 14.9 & 283.3 & 0.96 & 22.3 & 1.2 & 0.183 & 3.7 & 3.4 \\
\hline S15-3 & 8.6 & 25.7 & 11.0 & 2.2 & 1.5 & 4.9 & 209.6 & 0.91 & 12.7 & 0.8 & 0.175 & 6.0 & 3.3 \\
\hline S16-1 & 8.2 & 17.4 & 22.1 & 2.0 & 0.4 & 79.8 & 412.9 & 1.48 & 64.3 & 2.0 & 0.220 & 2.4 & 10.8 \\
\hline S16-2 & 8.2 & 10.4 & 23.1 & 3.6 & 0.3 & 10.9 & 291.6 & 1.33 & 28.5 & 0.9 & 0.263 & 3.7 & 4.7 \\
\hline S16-3 & 8.2 & 8.1 & 22.4 & 3.4 & 0.5 & 5.1 & 216.6 & 1.25 & 47.0 & 2.5 & 0.245 & 3.1 & 6.9 \\
\hline \multicolumn{14}{|c|}{ Post-antique long-term fallow land } \\
\hline S1-1 & 8.1 & 22.6 & 16.9 & 1.5 & 0.5 & 69.9 & 233.9 & 1.80 & 34.5 & 4.6 & 0.268 & 4.7 & 4.9 \\
\hline S1-2 & 8.2 & 14.9 & 15.8 & 1.5 & 0.5 & 110.3 & 353.8 & 1.65 & 16.8 & 0.9 & 0.240 & 6.0 & 2.5 \\
\hline S1-3 & 8.2 & 28.1 & 15.4 & 1.4 & 0.5 & 14.9 & 511.7 & 1.39 & 85.2 & 3.4 & 0.230 & 1.6 & 18.4 \\
\hline S3-1 & 8.2 & 29.1 & 18.7 & 2.3 & 0.3 & 4.9 & 424.2 & 2.22 & 20.1 & 1.0 & 0.225 & 6.8 & 7.6 \\
\hline S3-2 & 8.2 & 39.8 & 11.5 & 2.0 & 0.3 & 79.8 & 215.8 & 1.44 & 10.2 & 0.9 & 0.163 & 12.5 & 2.4 \\
\hline S14-1 & 8.1 & 19.2 & 13.6 & 1.6 & 0.4 & 10.9 & 368.9 & 1.97 & 25.3 & 1.9 & 0.260 & 5.3 & 5.8 \\
\hline S14-2 & 8.2 & 24.5 & 11.1 & 1.1 & 0.3 & 5.1 & 199.0 & 1.53 & 15.7 & 0.8 & 0.198 & 5.6 & 4.5 \\
\hline \multicolumn{14}{|c|}{ Modern-day plowed land } \\
\hline S6-1 & 7.5 & 1.8 & 19.8 & 2.4 & 0.5 & $78.4(173.6)^{\mathrm{a}}$ & $425.7(298.5)^{\mathrm{a}}$ & 1.80 & 25.6 & 3.2 & 0.138 & 14.5 & 5.8 \\
\hline S6-2 & 7.8 & 1.1 & 14.5 & 2.7 & 0.1 & $20.5(136.3)^{a}$ & $311.9(146.8)^{\mathrm{a}}$ & 1.58 & 25.5 & 1.0 & 0.195 & 5.1 & 5.9 \\
\hline S7-1 & 8.2 & 3.7 & 16.1 & 1.3 & 0.4 & 48.5 & 420.8 & 1.70 & 25.6 & 1.1 & 0.198 & 8.7 & 4.5 \\
\hline S7-2 & 7.8 & 7.6 & 22.1 & 2.6 & 0.6 & 8.4 & 222.3 & 1.50 & 24.5 & 3.6 & 0.233 & 7.5 & 2.5 \\
\hline S9-1 & 8.0 & 21.4 & 14.7 & 1.4 & 0.1 & 80.9 & 459.4 & 1.50 & 18.7 & 1.3 & 0.208 & 7.6 & 4.9 \\
\hline S9-2 & 8.2 & 23.3 & 14.6 & 1.7 & 0.1 & 16.2 & 248.3 & 1.15 & 15.8 & 1.4 & 0.215 & 6.2 & 3.1 \\
\hline \multicolumn{14}{|c|}{ Long-term fallow land in the modern era } \\
\hline S5-1 & 8.2 & 23.5 & 16.2 & 2.0 & 0.7 & 9.1 & 194.6 & 1.46 & 21.7 & 1.9 & 0.228 & 6.1 & 3.0 \\
\hline S5-2 & 8.4 & 17.3 & 17.3 & 3.3 & 0.8 & 5.8 & 215.5 & 1.46 & 20.8 & 1.2 & 0.153 & 9.3 & 4.7 \\
\hline S8-1 & 8.0 & 23.5 & 16.2 & 1.7 & 0.1 & 22.0 & 338.1 & 2.56 & 17.8 & 1.0 & 0.230 & 7.8 & 4.1 \\
\hline S8-2 & 8.1 & 24.1 & 23.5 & 1.2 & 0.1 & 7.7 & 217.8 & 2.35 & 29.6 & 1.6 & 0.213 & 7.6 & 5.6 \\
\hline S10-1 & 8.1 & 26.5 & 13.8 & 1.5 & 0.5 & 16.1 & 393.7 & 1.60 & 19.0 & 2.5 & 0.235 & 7.0 & 3.2 \\
\hline S10-2 & 8.2 & 28.3 & 18.5 & 1.5 & 0.5 & 8.6 & 127.3 & 1.27 & 72.3 & 0.8 & 0.230 & 1.5 & 11.7 \\
\hline S13-1 & 8.2 & 37.2 & 12.3 & 1.6 & 0.3 & 12.6 & 298.5 & 1.84 & 16.1 & 0.8 & 0.240 & 6.0 & 6.4 \\
\hline S13-2 & 8.3 & 39.9 & 10.6 & 1.1 & 0.5 & 8.6 & 176.3 & 1.46 & 9.5 & 0.5 & 0.173 & 7.9 & 4.5 \\
\hline
\end{tabular}

Abbreviations: $\mathrm{C}$ - total organic carbon (TOC); $\mathrm{C}_{\text {labile }}$ - labile fraction of TOC; $\mathrm{C}_{\mathrm{ha}}$ and $\mathrm{C}_{\mathrm{fa}}-$ carbon contents of humic and fulvic acids, respectively.

a Chirikov's method.

lowest values are recorded in the idle lands of the modern era and the virgin carbonated soils. The middle values (20-30\%) are characteristic of the post-antique idle lands, while the continually plowed soils, despite the widely varying values and the general decrease of SOM due to cultivation, show a tendency for a high degree of humification.

In the soils of the Chernozemic series, the reproduction of a certain amount of SOM, which ensures acceptable agrophysical properties of the plowed horizon, and of the quality of SOM, particularly of its labile part, is a priority in soil fertility management for sustainable land use.

\subsubsection{Geochemical properties}

The geochemical indicator $\mathrm{Si} /(\mathrm{Al}+\mathrm{Fe})$, which characterizes the processes of intra-soil chemical weathering, is also valuable for distinguishing between the virgin soils and the cultivated as well as idle lands of different periods (Table 9). The virgin soils on eluvium of dense carbonate rocks (S4, S11) have the lowest content of silica (15$16 \%)$, while in the cultivated soils the $\mathrm{Si} /(\mathrm{Al}+\mathrm{Fe})$ value is higher. Yet, in the agrogenic series, the plowed soils on eluvium retain their distinctiveness from those formed on loams. To a certain degree, the relative enrichment in silica of the plow zone can result from wind erosion, technological dusting and, to a lesser extent, from water erosion, as the soils under study are predominantly situated in the flat areas.

The processes of eluviation characterized by coefficient $\mathrm{K}_{\mathrm{e}}$ were found to be the most active in some soils of the modern-day plowed lands (Fig. 1: S6, S7), which can be explained by their genetic properties - they are Calcic Chernozems with secondary carbonates.

Good diagnostic capability for assessing the extent and duration of the agrogenic transformation of soils is demonstrated by the "coefficient of leaching' $\beta$ (Jenny, 1931), which is calculated as the ratio $\beta=b$ of soil (in horizon $n$ ) $/ b$ of rock, where $b=\left(\mathrm{K}_{2} \mathrm{O}+\mathrm{Na}_{2} \mathrm{O}\right) / \mathrm{Al}_{2} \mathrm{O}_{3}$. As alumina remains virtually immobile while all the other components are, to a greater or lesser extent, vulnerable to erosion during soil formation and weathering, the lower the $\beta$ value the bigger are the losses of alkalis as compared to that of alumina.

For the genetically specific soils (S6, S7) mentioned above it is natural that the $\beta$ values in the plow zone $\left(\beta_{1}\right)$ were, sometimes lower by $0.02-0.05$, than in the underlying horizon $\left(\beta_{2}\right)$. The process of active leaching observable in natural conditions occurs differently under the impact of agrogenesis. It has been demonstrated (Lisetskii, 2008) that the post-antique soils differ from the virgin ones by a, on average, $39 \pm 8 \%$ thicker humus horizon and a deeper, by $22 \pm 5 \%$, sinking of the new formations of $\mathrm{CaCO}_{3}$. This is explained by the intensification of the mineral mass hydrolysis in continually plowed lands with the increase of the incoming part of the water balance and formation of a periodical flushing regime.

Remarkably, the greatest difference between the $\beta_{1}$ and $\beta_{2}$ values (0.37) has been recorded in the continuously plowed lands near the ancient city of Kerkinitis (S15). This is probably due to these lands being subjected to agricultural stress for a longer duration than in other 
Table 9

Bulk chemical composition of soils of the agrogenic series (Horizon Ap).

\begin{tabular}{|c|c|c|c|c|c|c|c|c|c|c|c|c|c|c|c|c|c|c|}
\hline \multirow{2}{*}{$\begin{array}{l}\text { Chemical components and } \\
\text { geochemical indicators }\end{array}$} & \multirow[t]{2}{*}{ Units } & \multicolumn{2}{|l|}{$\mathrm{VL}$} & \multicolumn{3}{|l|}{ CPL } & \multicolumn{4}{|l|}{ PLFL } & \multicolumn{3}{|l|}{ MPL } & \multicolumn{4}{|l|}{ MLFL } & \multirow[t]{2}{*}{ Average } \\
\hline & & S4 & S11 & S12 & S15 & S16 & S1 & S2 & S3 & S14 & S6 & S7 & S9 & S5 & S8 & S10 & S13 & \\
\hline $\mathrm{SiO}_{2}$ & $\%$ & 15.7 & 15.4 & 42.5 & 38.8 & 48.4 & 44.6 & 46.2 & 34.2 & 41.8 & 57.6 & 53.6 & 43.5 & 43.7 & 42.0 & 40.9 & 28.3 & 39.8 \\
\hline $\mathrm{Al}_{2} \mathrm{O}_{3}$ & $\%$ & 6.2 & 8.1 & 10.0 & 9.1 & 11.0 & 10.9 & 11.0 & 9.2 & 9.9 & 11.0 & 11.4 & 10.0 & 9.0 & 10.4 & 9.7 & 8.7 & 9.7 \\
\hline $\mathrm{Fe}_{2} \mathrm{O}_{3}$ & $\%$ & 1.5 & 1.8 & 2.5 & 3.2 & 3.2 & 2.7 & 2.9 & 2.4 & 2.8 & 3.4 & 3.3 & 2.8 & 2.5 & 2.7 & 2.7 & 2.5 & 2.7 \\
\hline $\mathrm{CaO}$ & $\%$ & 35.9 & 33.6 & 16.0 & 14.2 & 10.4 & 13.7 & 10.6 & 20.0 & 13.1 & 1.3 & 3.8 & 12.4 & 11.2 & 14.4 & 14.8 & 22.9 & 15.5 \\
\hline $\mathrm{MgO}$ & $\%$ & 3.9 & 3.6 & 2.2 & 2.2 & 2.0 & 2.0 & 1.5 & 2.4 & 1.9 & 1.1 & 1.5 & 2.0 & 1.9 & 2.0 & 2.1 & 2.4 & 2.2 \\
\hline $\mathrm{Na}_{2} \mathrm{O}$ & $\%$ & 3.2 & 3.1 & 1.9 & 1.9 & 1.6 & 1.6 & 1.1 & 2.0 & 1.6 & 0.9 & 1.0 & 1.6 & 1.6 & 1.7 & 1.8 & 2.3 & 1.8 \\
\hline $\mathrm{K}_{2} \mathrm{O}$ & $\%$ & 1.4 & 1.4 & 1.6 & 1.4 & 1.7 & 1.7 & 1.8 & 1.4 & 1.6 & 2.0 & 1.7 & 1.6 & 1.7 & 1.5 & 1.5 & 1.3 & 1.6 \\
\hline $\mathrm{TiO}_{2}$ & $\%$ & 0.4 & 0.4 & 0.6 & 0.7 & 0.8 & 0.7 & 0.7 & 0.5 & 0.7 & 0.9 & 0.9 & 0.6 & 0.8 & 0.7 & 0.6 & 0.5 & 0.6 \\
\hline $\mathrm{P}_{2} \mathrm{O}_{5}$ & $\%$ & 0.3 & 0.2 & 0.2 & 0.1 & 0.1 & 0.2 & 0.2 & 0.2 & 0.2 & 0.1 & 0.1 & 0.2 & 0.2 & 0.2 & 0.1 & 0.2 & 0.2 \\
\hline MnO & $\%$ & 0.1 & 0.1 & 0.1 & 0.1 & 0.1 & 0.1 & 0.1 & 0.1 & 0.1 & 0.1 & 0.1 & 0.1 & 0.2 & 0.1 & 0.1 & 0.1 & 0.1 \\
\hline $\mathrm{Sr}$ & $\mathrm{mg} / \mathrm{kg}$ & 349 & 215 & 256 & 262 & 170 & 218 & 169 & 158 & 210 & 125 & 121 & 175 & 169 & 155 & 179 & 247 & 198.5 \\
\hline V & $\mathrm{mg} / \mathrm{kg}$ & 38.9 & 46.5 & 65.6 & 72.0 & 79.3 & 64.8 & 55.1 & 63.1 & 70.6 & 83.4 & 87.3 & 80.9 & 75.5 & 73.0 & 70.2 & 65.4 & 68.2 \\
\hline $\mathrm{Cr}$ & $\mathrm{mg} / \mathrm{kg}$ & 65.9 & 70.5 & 81.5 & 95.2 & 92.4 & 82.4 & 82.5 & 76.7 & 86.3 & 106 & 94.2 & 84.3 & 80.4 & 84.2 & 80.3 & 78.3 & 83.8 \\
\hline $\mathrm{Zn}$ & $\mathrm{mg} / \mathrm{kg}$ & 61.2 & 65.2 & 71.4 & 105 & 81.9 & 72.6 & 88.5 & 67.9 & 71.1 & 75.1 & 74.7 & 71.0 & 66.3 & 68.5 & 70.8 & 67.6 & 73.7 \\
\hline $\mathrm{Ni}$ & $\mathrm{mg} / \mathrm{kg}$ & 25.1 & 30.6 & 40.3 & 58.3 & 52.7 & 45.0 & 46.4 & 41.2 & 44.3 & 52.5 & 51.3 & 45.4 & 42.0 & 44.3 & 44.1 & 39.1 & 43.9 \\
\hline $\mathrm{Cu}$ & $\mathrm{mg} / \mathrm{kg}$ & 6.7 & 20.0 & 29.5 & 46.2 & 45.1 & 37.0 & 38.0 & 32.9 & 37.9 & 54.8 & 51.9 & 39.6 & 33.1 & 41.5 & 37.1 & 30.1 & 36.4 \\
\hline $\mathrm{Pb}$ & $\mathrm{mg} / \mathrm{kg}$ & 14.5 & 12.6 & 16.8 & 21.9 & 19.2 & 15.7 & 20.7 & 13.7 & 17.5 & 19.4 & 25.8 & 16.8 & 23.9 & 21.4 & 15.5 & 20.9 & 18.5 \\
\hline $\mathrm{Zr}$ & $\mathrm{mg} / \mathrm{kg}$ & $\mathrm{n} / \mathrm{d}$ & 118 & 263 & 246 & 272 & 289 & $\mathrm{n} / \mathrm{d}$ & 216 & 259 & 398 & 329 & 259 & 298 & 258 & 227 & 209 & 260.1 \\
\hline Сo & $\mathrm{mg} / \mathrm{kg}$ & 2.0 & 2.8 & 10.9 & 14.5 & 17.7 & 11.9 & 17.1 & 8.6 & 11.9 & 17.1 & 17.4 & 10.4 & 11.9 & 11.1 & 11.2 & 9.8 & 11.6 \\
\hline $\mathrm{Si} /(\mathrm{Al}+\mathrm{Fe})$ & Dimensionless & 1.59 & 1.22 & 2.61 & 2.36 & 2.61 & 2.54 & 2.57 & 2.29 & 2.52 & 3.05 & 2.79 & 2.60 & 2.92 & 2.45 & 2.53 & 1.93 & 2.41 \\
\hline$\left(\mathrm{K}_{2} \mathrm{O}+\mathrm{Na}_{2} \mathrm{O}\right) / \mathrm{Al}_{2} \mathrm{O}_{3}$ & Dimensionless & 0.72 & 0.56 & 0.34 & 0.36 & 0.29 & 0.31 & 0.26 & 0.38 & 0.32 & 0.26 & 0.24 & 0.32 & 0.37 & 0.31 & 0.34 & 0.41 & 0.36 \\
\hline$(\mathrm{CaO}+\mathrm{MgO}) / \mathrm{Al}_{2} \mathrm{O}_{3}$ & Dimensionless & 6.41 & 4.60 & 1.81 & 1.80 & 1.12 & 1.44 & 1.10 & 2.44 & 1.51 & 0.22 & 0.46 & 1.44 & 1.46 & 1.57 & 1.74 & 2.92 & 2.00 \\
\hline $\mathrm{K}_{\mathrm{e}}$ & Dimensionless & 0.35 & 0.37 & 1.96 & 1.96 & 3.08 & 2.34 & 3.06 & 1.32 & 2.29 & 10.8 & 6.70 & 2.46 & 2.64 & 2.14 & 2.02 & 0.97 & 2.78 \\
\hline $\mathrm{R}_{\mathrm{n}}^{\mathrm{a}}$ & Dimensionless & 1.39 & 1.35 & 1.27 & 1.31 & 1.27 & 1.31 & 1.30 & 1.38 & 1.28 & 1.30 & 1.30 & 1.28 & 1.40 & 1.37 & 1.27 & 1.38 & 1.32 \\
\hline
\end{tabular}

Abbreviations: VL - virgin land; MLFL - long-term fallow land in the modern era; MPL - modern-day plowed land; PLFL - post-antique long-term fallow land; CPL - continually plowed land.

a For soils from sites S3-5, S8, S11 and S13 (on eluvium of carbonate rocks), coefficient $\mathrm{R}_{\mathrm{n}}$ is calculated on the basis of six elements (Ti, Zn, Pb, Ca, P, K); for other soils (on loams) by nine elements (Ni, Zn, Mn, Pb, Cu, Si, Co, P, K). 
parts of the Tarkhankut Peninsula. In the post-antique idle lands, the difference in values $\beta_{1}$ and $\beta_{2}$ is somewhat smaller (up to 0.18 ) than in the continually plowed lands. The same peculiarity has also been noted in the top part of an ancient earthen division wall (S1) suggesting that the surface of these walls might have been cultivated in the Greek period, for instance, for the purpose of viti- and/or horticulture. Soils of the newly developed lands have $\beta_{1}>\beta_{2}$ (except for S10 where the values are fairly similar).

The ratio between the mobile components and a stable component of the soil (in our case alumina) is indicative of the intensity of processes of chemical decomposition and eluviation. Using the molecular ratios of oxides $\left(\mathrm{K}_{2} \mathrm{O}+\mathrm{Na}_{2} \mathrm{O}\right) / \mathrm{Al}_{2} \mathrm{O}_{3}$ and $(\mathrm{CaO}+\mathrm{MgO}) / \mathrm{Al}_{2} \mathrm{O}_{3}$, a more active, cultivation-conditioned transformation of $\mathrm{Ca}$ and $\mathrm{Mg}$, as compared to $\mathrm{K}$ and $\mathrm{Na}$, was established in comparable soils of the agrogenic series (in objects S3, S8, and S13 as compared to S4 and S11). The continuously plowed lands and the post-antique idle lands differ considerably from other soils in terms of another indicator used in our analysis, namely, the decrease of molar ratio $\mathrm{CaO} / \mathrm{ZrO}_{2}$ in the plow zone as a result of more intensive and/or more prolonged agricultural stress since the minerals containing calcium are more easily weathered than those with the chemically stable and biologically inert zirconium. The same peculiarity has also been found in the soil at S5, which initially seemed to be a postantique idle land.

Of particular interest is the depletion of microelements in plowed soils compared to virgin lands: on average, in the continuously plowed soils, the $R_{n}$ value is $6 \%$ lower, whereas in the plowed lands of the modern era and post-antique idle lands this value is $5 \%$ lower. Thus in Chernozems, the prolonged agrogenic stresses lead to a reduced amount of microelements such as $\mathrm{Co}, \mathrm{Ni}, \mathrm{Mn}, \mathrm{Cu}, \mathrm{Zn}, \mathrm{Pb}$, as well as phosphorus and potassium.

\subsection{Indicators of agrogenesis}

Not all of the soil properties can be linked directly to the duration and intensity of agrogenic transformation. The initial pedogenetic differences of soils are not completely erased by subsequent agricultural development. But, it has been possible to determine a set of universal indicators of agrogenesis that are more sensitive to agricultural use.

The question arises whether the long periods of regeneration (in our case, 2300 years) can return the soils cultivated in antiquity to the state and properties characteristic of the virgin soils. In other words, what is the position of the post-agrogenic idle lands within the agrogenic sequence of soils: before the idle lands of the modern era or after?

A unique opportunity for comprehending the role of slow-acting processes of pedogenesis is offered by the continuously plowed soils. The soils cultivated in classical antiquity have undergone the same agrogenic transformation as the newly developed soils of the modern era. Nevertheless, they have remained distinguishable from the latter through the relict traits accumulated during previous periods of cultivation.

As can be seen in the dendrogram in Fig. 2, soils of the agrogenic series form two large clusters: cultivated and uncultivated soils. All plowed soils and those occupied by natural or semi-natural steppe vegetation form clusters with a smaller inter-cluster distance. Thus, the cluster analysis supports the selection of indicators of agrogenesis.

The heuristic potential of these indicators serves as an additional validation of their selection. Prior to the field investigation, the soil at site S5 was identified as idle land of the modern era. As can be seen on an archival aerial photo from the 1950s, there was a cultivated field here. In 1967, this area was plowed for planting fruit trees or vines, but quickly abandoned, and in 1970, an airfield was built on the plot. The analytical results have demonstrated, however, that the soil of S5 differs from the recent idle lands ( sites S8, S10 and S13) in four out of five indicators of agrogenesis (except APS index), resembling instead the post-antique idle lands. Such re-attribution is supported by archaeological evidence, namely, the presence of the 4th-2nd century BC Greek settlement of

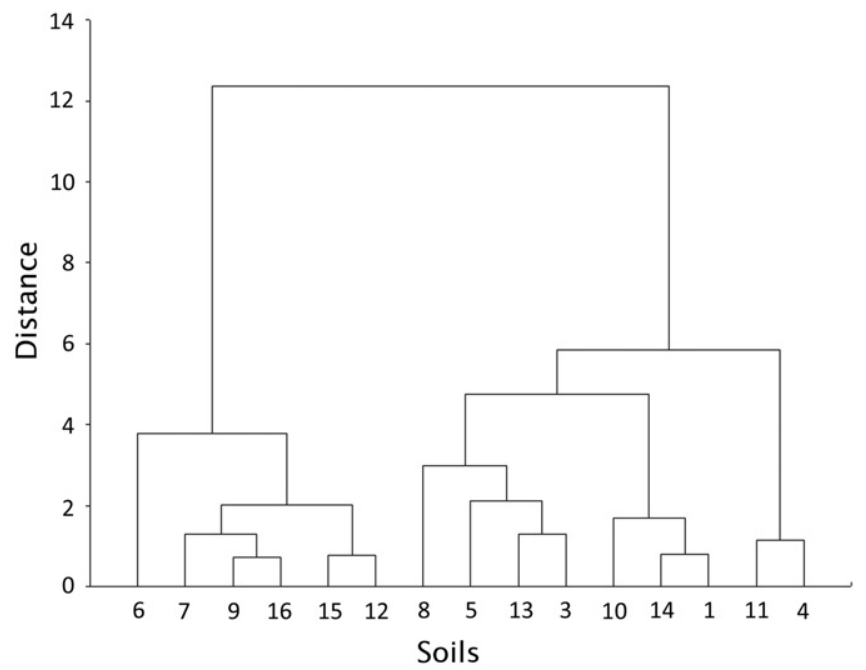

Fig. 2. Results of the cluster analysis of soils of the agrogenic series according to indicators of agrogenesis (APS, SOC, $\mathrm{P}_{2} \mathrm{O}_{5}, \mathrm{R}_{\mathrm{n}}, \mathrm{K}_{\mathrm{e}}$ ). Note: Site numbers on axis $\mathrm{X}$ correspond to those in Table 1.

Mezhvodnoe situated just $1.4 \mathrm{~km}$ east of site S5 (Stolba, 2012). The traces of ancient land division revealed in its surroundings (Chtcheglov, 1992) leave little room for doubt about this area's agriculture heritage in the late Classical and early Hellenistic periods.

The quality of soils (SQ) of the agrogenic series was evaluated by calculating the geometrical mean value on the basis of the most informative indicators of agrogenesis: the quantity (SOC) and quality $\left(\mathrm{C}_{\mathrm{ha}} / \mathrm{SOC}\right)$ of SOM, amount of mobile phosphates, agrophysical condition of the soil (based on APS index), eluviation coefficient and average quantitative estimate of the soil's capability to accumulate elements ( $\mathrm{Ni}, \mathrm{Zn}, \mathrm{Mn}, \mathrm{Pb}, \mathrm{Cu}, \mathrm{Si}, \mathrm{Co}, \mathrm{P}, \mathrm{K}$ ). Fig. 3 demonstrates that, despite the differences in duration of cultivation (from 220 to 800 years), the continuously plowed soils form a compact group with close values of soil quality (SQ). This indicates that, after attaining a certain level of equilibrium with the changing environmental factors, the process of agrogenic transformation of soils slows down considerably.

Even after 2000 years of renaturation, soils of the post-antique idle lands retain in their 'memory' agrogenic pedorecords, at least according

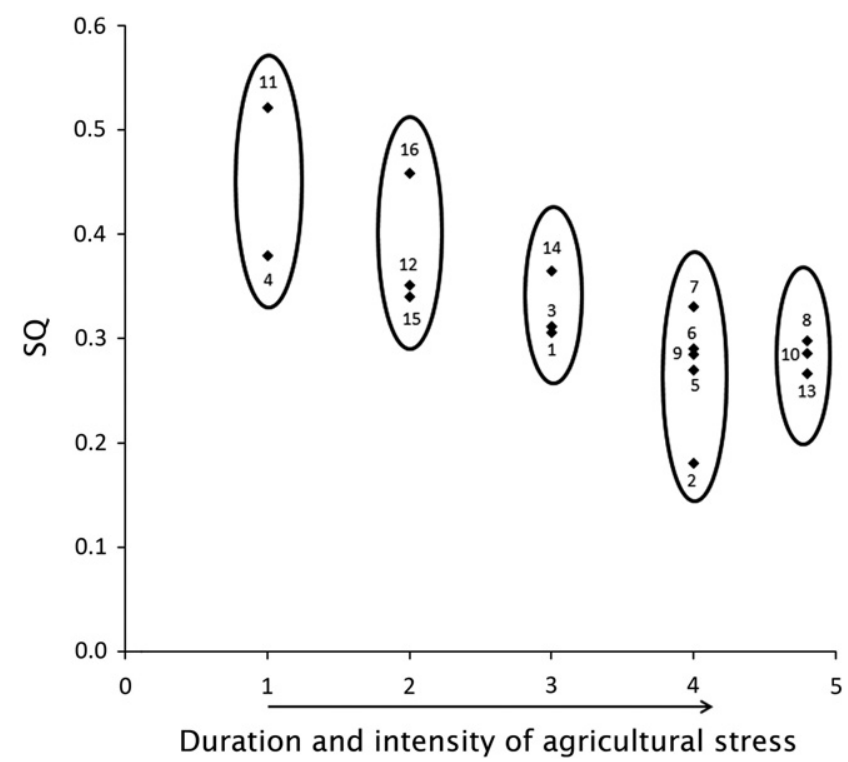

Fig. 3. Dependence of soil quality (SQ) on the duration and intensity of agricultural stress in the ranked series of soils of the agrogenic series (1-5). Key: 1 - virgin land; 2 -idle land in the modern era; 3 - modern-day plowed land; 4 - post-antique idle land; 5 - continually plowed land. 
to the aggregate of the indicators listed above. According to indicator $\mathrm{SQ}$, the overall transformation of soils of the current stage of development (150-165 years) is about $15 \%$ lower as compared to continuously plowed soils. Under fallowing conditions, they are capable of fast regeneration within a few decades. It therefore seems that resource-saving sustainable agriculture could benefit from management methods that incorporate a fallowing regime.

\section{Conclusions}

1. Among the numerous physical and chemical properties of soils, the most informative indicators of agrogenesis have been defined. This was facilitated by the fact that the studies were conducted in a region where the onset of large-scale systematic farming coincides with Greek colonization. A long agricultural history with various practices of land use made it possible to group the attributed and parameterized soil objects into the chronosequence: virgin land, post-antique idle land, continually plowed land, modern-day plowed land, and idle land in the modern era. The informative potential of the soils, which continually (or with some restorative phases) underwent long-term agricultural stress under different practices of farming, provides insight into the long-term transformations of the material and energetic structure of soils.

2. The new method of calculating an integral agrophysical soil indicator based on structural properties, cloddiness and water stability, amount of water-stable aggregates and their mean mass-weighted diameter has allowed the grouping of the studied objects into a ranked sequence: post-antique idle land $<$ virgin $<$ idle land in the modern era $<$ continually plowed land $<$ modern-day plowed land. Thus, prior practices of land use have a positive effect on the agrophysical soil properties.

The reproduction of soil organic matter (SOM) and its quality, particularly of its labile content, which is responsible for the agrophysical properties of a plow horizon, is key to soil fertility management in sustainable agriculture.

3. It has been established that the reproduction of soil organic matter (SOM) and its quality, particularly its labile content which affects the agrophysical properties of a plow zone, is the first priority for management of soil fertility in a sustainable agriculture. Observations suggest that one effect of long-term agrogenic stresses is a $5-6 \%$ reduction in microelements in plowed soils compared with virgin soils.

4. It has been shown that even after two millennia of renaturation the post-antique idle lands preserve the footprints of agrogenesis, which in the form of an aggregate of diagnostic soil properties define pedomemory. According to soil quality, the overall agrogenic transformation of soils of the current phase of development (150165 years) is $15 \%$ lower than for the continuously plowed soils. If abandoned, as is often the case for soils of medium and poor quality on the northern coast of the Black Sea, the arable lands are capable of fast regeneration within a few decades of the fallowing regime. Therefore, management methods that incorporate a fallowing regime have great potential in resource-saving sustainable agriculture.

\section{Acknowledgments}

This study was carried out with financial support from the Danish Council for Independent Research | Humanities (grant no. 09-069235) and the Ministry of Education and Science of the Russian Federation (as part of the state assignment for the Belgorod State National Research University; activity type: 'Organization of Scientific Research'; no. 2014/ $420-1$ ). The authors also wish to thank the anonymous reviewers for their detailed and constructive comments which greatly contributed to the improvement of our manuscript.

\section{References}

Andrianov, P.I., 1947. Strength of soil lump and methods of its determination. Pochvovedenie 2, 96-101 (in Russian).

Arinushkina, E.V., 1970. Manual for the Chemical Analysis of Soils. University Press, Moscow (in Russian).

Bellin, N., van Wesemael, B., Meerkerk, A., Vanacker, V., Barbera, G.G., 2009. Abandonment of soil and water conservation structures in Mediterranean ecosystems. A case study in south east Spain. Catena 76, 114-121.

Blake, L., Goulding, K.W.T., Mott, C.J.B., Poulton, P.R., 2000. Temporal changes in chemical properties of air-dried stored soils and their interpretation for long-term experiments. Eur. J. Soil Sci. 51, 345-353.

Bondarenko, O.Yu, Vasil'eva, T.V., 2008. Transformation of ecological and coenotic structure of flora in the abandoned agrarian lands in southern Ukraine. Restoration of disturbed natural ecosystems. Lebed'; Donezk, in Ukrainian, pp. 77-80.

Bryant, R.B., Galbraith, J.M., 2003. Incorporating anthropogenic processes in soil classification. In: Eswaran, H., et al. (Eds.), Soil Classification: A Global Desk Reference. CRC Press, Boca Raton, pp. 57-66 (Fla.).

Bulygin, S.Yu, Nearing, M.A., 1999. Formation of Ecologically Balanced Agrolandscapes: The Problem of Soil Erosion. Eney Ltd., Kharkiv (in Ukrainian).

Chtcheglov, A., 1992. Polis et chora: Cité et territoire dans le Pont-Euxin. Les Belles Lettres, Paris.

Cordova, C.E., Lehman, P.H., 2005. Holocene environmental change in southwestern Crimea (Ukraine) in pollen and soil records. The Holocene 15, 263-277.

Cordova, C.E., Gerasimenko, N.P., Lehman, P.H., Kliukin, A.A., 2011. Late Pleistocene and Holocene paleoenvironments of Crimea: Pollen, soils, geomorphology, and geoarchaeology. In: Buynevich, I.V., Yanko-Hombach, V., Gilbert, A.S., Martin, R.E. (Eds.), Geology and Geoarchaeology of the Black Sea Region: Beyond the Flood HypothesisGSA Special Papers 473. Geological Society of America, Boulder, pp. 133-164.

Delgado, R., Martín-García, J.M., Calero, J., Casares-Porcel, M., Tito-Rojo, J., Delgado, G., 2007. The historic man-made soils of the Generalife garden (La Alhambra, Granada, Spain). Eur. J. Soil Sci. 58, 215-228.

Dick, R.P., Sandor, J.A., Eash, N.S., 1994. Soil enzyme activities after 1500 years of terrace agriculture in the Colca Valley, Peru. Agric. Ecosyst. Environ. 50, 123-131.

Dolotov, V.A., 1984. Old-arable soil as used for two thousand years. Pochvovedenie 1, 103-106 (in Russian).

Eash, N.S., Sandor, J.A., 1995. Soil chronosequence and geomorphology in a arid valley in the Andes of southern Peru. Geoderma 65, 59-79.

Fonte, S.J., Vanek, S.J., Oyarzun, P., Parsa, S., Quintero, D.C., Rao, I.M., Lavelle, P., 2012. Pathways to agroecological intensification of soil fertility management by smallholder farmers in the Andean Highlands. Adv. Agron. 116, 125-184

Freppaz, M., Agnelli, A., Drusi, B., Stanchi, S., Galliani, C., Revel Chion, V., Zanini, E., 2008. Soil quality and fertility: studies in the Valle d'Aosta. In: Fontanari, E., Patassini, D. (Eds.), Terraced Landscapes of the AlpsProjects in Progress. Marsilio, Venice, pp. 37-39.

Gerasimenko, N.P., 2011. Climatic and environmental oscillations in southeastern Ukraine from 30 to $10 \mathrm{ka}$, inferred from pollen and lithopedology. In: Buynevich, I.V., YankoHombach, V., Gilbert, A.S., Martin, R.E. (Eds.), Geology and Geoarchaeology of the Black Sea Region: Beyond the Flood HypothesisGSA Special Papers 473. Geological Society of America, Boulder, pp. 117-132.

Gerrard, A.J., 1981. Soils and Landforms: An Integration of Geomorphology and Pedology. George Allen \& Unwin, London.

Goldberg, P., MacPhail, R., 2006. Practical and Theoretical Geoarchaeology. Blackwell Publishing Ltd., New York.

Gong, Z., Putian, L., Jie, C., Xuefeng, H., 2000. Classical farming systems of China. J. Crop. Prod. 3, 11-21.

Goodman-Elgar, M., 2008. Evaluating soil resilience in long-term cultivation: a study of pre-Columbian terraces from Paca Valley, Peru. J. Archaeol. Sci. 35, 3072-3086.

Harden, C., 1996. Interrelationships between abandonment and land degradation: a case from the Ecuadorian Andes. Mt. Res. Dev. 16, 274-280.

Homburg, J.A., Sandor, J.A., 2011. Anthropogenic effects on soil quality of ancient agricultural systems of the American Southwest. Catena 852, 144-154.

IUSS Working Group WRB, 2014. World Reference Base for Soil Resources 2014. International soil classification system for naming soils and creating legends for soil maps. World Soil Resources Reports 106. FAO, Rome.

Ivanov, I.V., Alexandrovskiy, A.L., 1987. Methods for the study of the evolution of soils. Sov. Soil Sci. 19, 90-101.

Jenny, H., 1931. Behavior of potassium and sodium during the process of soil formation. Mo. Agric. Exp. Station Res. Bull. 162, 42-52.

Jenny, H., 1941. Factors of Soil Formation. Mc Graw-Hill, New York.

Karavaeva, N.A., 2000. Long-term agrogenic evolution of soddy-podzolic soil. Eurasian Soil Sci. 33, 147-155.

Karavaeva, N.A., Zharikov, S.N., Konchin, A.E., 1985. Arable soils of the Non-Chernozem area: a process-evolutional approach to studies. Pochvovedenie 11, 114-125 (in Russian).

Kolotukhin, V.A., 2003. Late Bronze Age of the Crimea. Stilos, Kiev (in Russian).

Korobov, D.S., Borisov, A.V., 2013. The origins of terraced field agriculture in the Caucasus: new discoveries in the Kislovodsk basin. Antiquity 87, 1-18.

Korpusova, V.N., Lyashko, S.N., 1990. Catacomb burial with wheat in the Crimea. Sov. Archeol. 3, 166-175

Kostyuchenko, V.P., Lisitsyna, G.N., 1976. Genetic features of ancient-irrigated soils. Pochvovedenie 2, 3-13.

Krupenikov, I.A., 2005. Typification of the anthropogenic processes of degradation of chernozems. Eurasian Soil Sci. 38, 1347-1354. 
Lisetskii, F.N., 1998. Autogenic succession of steppe vegetation in postantique landscapes. Russ. J. Ecol. 4, 217-219.

Lisetskii, F.N., 2008. Agrogenic transformation of soils in the dry steppe zone under the impact of antique and recent land management practices. Eurasian Soil Sci. 8, 805-817.

Lisetskii, F.N., Ergina, E.I., 2010. Soil development on the Crimean Peninsula in the Late Holocene. Eurasian Soil Sci. 43, 601-613.

Lisetskii, F.N., Rodionova, M.E., 2012. Soil and landscape changes in ancient agricultural areas (exemplified by antique Olbia). Geogr. Nat. Resour. 33, 327-335.

Lisetskii, F.N., Stolba, V.F., Ergina, E.I., Rodionova, M.E., Terekhin, E.A., 2013. Post-agrogenic evolution of soils in ancient Greek land use areas in the Herakleian Peninsula, SouthWest Crimea. The Holocene 23, 504-514.

Lisitsyna, G.N., Kostyuchenko, V.P., 1976. Soil as a source of information in studies of ancient agriculture (after the results of investigations in arid regions of the USSR in 1969-1973). Sov. Archeol. 1, 23-41 (in Russian).

Liu, G., Li, L., Wu, L., Wang, G., Zhou, Z., Du, S., 2009. Determination of soil loss tolerance of an entisol in Southwest China. Soil Sci. Soc. Am. J. 73, 412-417.

Londono, A.C., 2008. Pattern and rate of erosion inferred from Inca agricultural terraces in arid Southern Peru. Geomorphology 99, 13-25.

Machigin, B.P., 1952. Methods of Agrochemical, Agrophysical and Microbiological Research in Irrigated Cotton Areas. AN UzSSR, Tashkent (In Russian).

Matviishina, Zh.M. (Ed.), 2010. Spatial and Temporal Correlation of Palaeogeographic Conditions of the Quaternary Period in the Territory of Ukraine. Naukova dumka, Kiev (in Ukrainian).

Mighall, T.M., Foster, I.D.L., Rowntree, K.M., Boardman, J., 2012. Reconstructing recent land degradation in the semi-arid Karoo of South Africa: a palaeoecological study at Compassberg, Eastern Cape. Land Degrad. Dev. 23, 523-533.

Miralles, I., Ortega, R., Almendros, G., Sánchez-Marañón, M., Soriano, M., 2009. Soil quality and organic carbon ratios in mountain agroecosystems of South-east Spain. Geoderma 150, 120-128.

Miyaji, A., 2003. Analysis of Cultivated Fields and Their Soils in Japanese Archaeology: Soil Micromorphology. In: Boschian, G., Langohr, R., Limbrey, S., Macphail, R.I. (Eds.), Second International Conference on Soils and Archaeology, Pisa, 12th-15th May, 2003. Felici, Pisa.

Nyberg, G., Bargués Tobella, A., Kinyangi, J., Ilstedt, U., 2012. Soil property changes over a 120 -yr chronosequence from forest to agriculture in western Kenya. Hydrol. Earth Syst. Sci. 16, 2085-2094.

Orlov, D.S., Biryukova, O.N., Rozanova, M.S., 2004. Revised system of the humus status parameters of soils and their genetic horizons. Eurasian Soil Sci. 37, 798-805.

Phillips, J.D., 2009. Soils as extended composite phenotypes. Geoderma 149, 143-151.

Pietsch, D., Mabit, L., 2012. Terrace soils in the Yemen Highlands: using physical, chemical and radiometric data to assess their suitability for agriculture and their vulnerability to degradation. Geoderma 185-186, 48-60.

Polyakova, N.V., Platonycheva, Yu.N., 2012. Some regularities of anthropogenic transformation of gray forest soils. Russ. Agric. Sci. 38, 297-300.

Ponomareva, V.V., Plotnikova, T.A., 1980. Humus and Soil Formation. Nauka, Leningrad (In Russian).

Ruecker, G., Schad, P., Alcubilla, M.M., Ferrer, C., 1998. Natural regeneration of degraded soils and site changes on abandoned agricultural terraces in Mediterranean Spain. Land Degrad. Dev. 19, 488-501.
Sanchez-Maranon, M., Soriano, M., Delgado, G., Delgado, R., 2002. Soil quality in Mediterranean mountain environments: effects of land use change. Soil Sci. Soc. Am. J. 66 948-958.

Sandor, J.A., 2006. Ancient agricultural terraces and soils. In: Warkentin, B. (Ed.), Footprints in the Soil: People and Ideas in Soil History. Elsevier, Amsterdam, pp. 505-534

Sandor, J.A., Eash, N.S., 1995. Ancient agricultural soils in the Andes of South Peru. Soil Sci. Soc. Am. J. 59, 170-179.

Sandor, J.A., Gersper, P.L., Hawley, J.W., 1990. Prehistoric agricultural terraces and soils in the Mimbres Area, New Mexico. World Archaeol. 22, 70-86.

Sapelko, T.V., Subetto, D.A., 2007. Vegetation change reconstruction during the Holocene in the north-western Crimea, based on pollen data. In: Yanko-Hombach, V. (Ed.), Extended Abstracts IGCP 521-481 Joint Meeting and Field Trip, GelendzhikKerch, September 8-17, 2007. Rosselkhozakademiya Printing House, Moscow, pp. 135-136.

Scalenghe, R., Bonifacio, E., Celi, L., Ugolini, F.C., Zanini, E., 2002. Pedogenesis in disturbed Alpine soils. Geoderma 109, 207-224.

Shaw, D.M., 1964. Interprétation geochimique des éléments en traces dans les roches cristallines. Masson, Paris.

Shcheglov, A.N., 1963. Excavations at the settlement of Tarpanchi in 1960. Soobš. Chers. Muz. 3, 67-75 (In Russian).

Slepetiene, A., Slepetys, J., 2005. Status of humus in soil under various long-term tillage systems. Geoderma 127, 207-215.

Stanchia, S., Freppaza, M., Agnellib, A., Reinschc, T., Zaninia, E., 2012. Properties, best management practices and conservation of terraced soils in Southern Europe (from Mediterranean areas to the Alps): a review. Quat. Int. 265, 90-100.

Stolba, V.F., 2005a. Monetary crises in the early Hellenistic poleis of Olbia, Chersonesos and Pantikapaion. A re-assessment. In: Alfaro, C., Marcos, C., Otero, P. (Eds.), XII Congreso Internacional de Numismática, Madrid 2003Actas-Proceedings-Actes. Ministerio de Cultura, Madrid, pp. 395-403.

Stolba, V.F., 2005b. The oath of Chersonesos and the Chersonesean economy in the early Hellenistic period. In: Archibard, Z.H., Davis, J.K., Gabrielsen, V. (Eds.), Making, Moving and Managing: The New World of Ancient Economies, 323-31 BC. Oxbow, Oxford, pp. 298-321.

Stolba, V.F., 2012. La vie rural en Crimée antique: Panskoe et ses environs. Études Let. 1-2, 311-364.

Stolba, V.F., Subetto, D.A., Sapelko, T.V., 2012. Paleo-limnological investigations in Lake Džarylgač. In: Bilde, P.G., Attema, P., Winther-Jacobsen, K. (Eds.), The Džarylgač Survey Project. University Press, Aarhus, pp. 49-50.

Storie, R.E., 1978. Storie Index Soil Rating. Division of Agricultural Sciences, University of California, Berkeley.

Vadyunina, A.F., Korchagina, Z.A., 1961. Methods for Investigating the Physical Properties of Soils and Earth Materials (in Field and Laboratory). Vysshaya shkola, Moscow (in Russian).

Veklich, M.F., Sirenko, N.A., 1974. Regionalization of the Plains in Southern Ukraine on the Basis of Palaeogeographic Data. In: Veklich, M.F. (Ed.), Palaeogeography and Engineering Geology of southern Ukraine (Late Cainozoic). AN USSR, Kiev (in Russian), pp. 34-44.

Wilkinson, T.J., 2003. Archaeological Landscapes of the Near East. University of Arizona Press, Tucson. 